\title{
An Advanced All Phosphate Lithium-Ion Battery Providing High Electrochemical Stability, High Rate Capability and Long-Term Cycling Performance
}

\author{
Shicheng Yu,,${ }^{\text {a,b,z }}$ Andreas Mertens,,${ }^{\text {a,b,c }}$ Roland Schierholz, ${ }^{\text {a Xin Gao, }},{ }^{\mathrm{a}, *}$ Özgür Aslanbas,,${ }^{\text {a,b }}$ \\ Josef Mertens, ${ }^{a}$ Hans Kungl, ${ }^{a}$ Hermann Tempel, ${ }^{\text {a,z }}$ and Rüdiger-A. Eichel ${ }^{a, b, c, d}$ \\ ${ }^{a}$ Institute of Energy and Climate Research, Forschungszentrum Jülich, IEK-9, D-52425 Jülich, Germany \\ ${ }^{b}$ Institut für Physikalische Chemie, RWTH Aachen University, D-52074 Aachen, Germany \\ ${ }^{c}$ Helmholtz-Institute Münster (HI MS) - Ionics in Energy Storage, D-48149 Münster, Germany \\ ${ }^{d}$ Section JARA-Energy, Jülich-Aachen Research Alliance, Jülich, Germany
}

\begin{abstract}
High rate capability and long-term cycling spindle-like $\mathrm{LiTi}_{2}\left(\mathrm{PO}_{4}\right)_{3} / \mathrm{C}$ anode and needle-like $\mathrm{Li}_{3} \mathrm{~V}_{2}\left(\mathrm{PO}_{4}\right)_{3}$ cathode have been evaluated in half-cell, and combined to fabricate an advanced fast cyclable all phosphate lithium-ion battery. The electrode materials with well-defined morphology were prepared by a solvothermal reaction followed by annealing, delivering capacities of 115.0 and $118.1 \mathrm{mAh} \cdot \mathrm{g}^{-1}$ at $25^{\circ} \mathrm{C}$ over 200 cycles at $0.5 \mathrm{C}$, respectively. For the full cell assembly, no prelithiation process is needed for the selected electrode pair due to their mutually matched capacity and stoichiometric amount of lithium-ions. The fabricated full cell, with an output voltage of more than $1.5 \mathrm{~V}$, inherits a superior rate capability and cycling performance of its electrodes. A discharge capacity of $36 \mathrm{mAh} \cdot \mathrm{g}^{-1}$ at $30 \mathrm{C}$ (about $30 \%$ of the initial discharge capacity at $0.1 \mathrm{C}$ ) and a capacity retention of $\sim 35 \%$ at $5 \mathrm{C}$ over 1000 cycles has been achieved. Furthermore, one of the most important reasons for the capacity fading in the full cell during long-term cycling is found to be a decomposition and structural degradation of $\mathrm{Li}_{3} \mathrm{~V}_{2}\left(\mathrm{PO}_{4}\right)_{3}$ cathode material.

(C) The Author(s) 2017. Published by ECS. This is an open access article distributed under the terms of the Creative Commons Attribution 4.0 License (CC BY, http://creativecommons.org/licenses/by/4.0/), which permits unrestricted reuse of the work in any medium, provided the original work is properly cited. [DOI: 10.1149/2.1151702jes] All rights reserved.

(cc) BY
\end{abstract}

Manuscript submitted September 26, 2016; revised manuscript received November 18, 2016. Published January 5, 2017.

Lithium-ion batteries are widely used in portable electronics and are a promising energy storage system for electric vehicles because of their high energy density and long cycle life. ${ }^{1,2}$ However, current lithium-ion battery technologies are still far from satisfaction to meet the increasingly diverse range of applications. For instance, the use of lithium-ion cells in large scale applications, such as electric vehicles, demands high charge/discharge cycling performance and an inherent high thermal stability. ${ }^{3,4}$ Micro-lithium-ion batteries which can be applied to human body require in first instance the considerations of safety issue and cycling performance. ${ }^{5,6}$ For the development of a novel type of lithium-ion battery like all-solid-state lithium-ion battery, one of the urgent needs to be addressed is to improve the ionic and electronic conductivity among the whole battery system. ${ }^{7,8}$ Additionally, high rate performance and long cycle life are required for lithium-ion battery as stationary application for power management. ${ }^{9}$ To advance the battery technologies according the desired applications, it is important to explore the cathode and anode materials, and match them reasonably and to investigate their electrochemical performances. ${ }^{10-12}$

Reasonable candidates of cathode materials such as $\mathrm{Li}_{\mathrm{x}} \mathrm{M}_{\mathrm{y}}\left(\mathrm{PO}_{4}\right)_{3}{ }^{13,14} \mathrm{Li}_{\mathrm{x}} \mathrm{M}_{\mathrm{y}} \mathrm{SiO}_{4}{ }^{15,16}$ and $\mathrm{Li}_{\mathrm{x}} \mathrm{M}_{\mathrm{y}} \mathrm{PO}_{4} \mathrm{~F}^{17,18}$ have attracted much attention because more than two formula units of Li-ions can possibly intercalate/deintercalate into/from their host crystal structure during discharge/charge at a moderate working potential. On the basis of the crystal structure in these cathode materials, the use of phosphate polyanions $\left(\mathrm{PO}_{4}\right)^{3-}$ is considered as a potential alternative to oxide-based cathodes. The strong $\mathrm{P}-\mathrm{O}$ bonds and the framework of $\left(\mathrm{PO}_{4}\right)^{3-}$ anions can guarantee both the dynamic and thermal stabilities required to fulfill the safety requisites in high-power applications. ${ }^{18}$ More than that, phosphate materials are also believed to be superior candidates of anode and solid electrolyte for lithium-ion battery owing their intrinsic high ionic conductivity and stability. ${ }^{19,20}$ Among these phosphate-materials, monoclinic lithium vanadium phosphate $\mathrm{Li}_{3} \mathrm{~V}_{2}\left(\mathrm{PO}_{4}\right)_{3}(\mathrm{LVP})$ is known to have two electrochemical windows for operation, $3.0 \sim 4.3 \mathrm{~V} \mathrm{vs.} \mathrm{Li}^{+} / \mathrm{Li}$ and $3.0 \sim 4.8 \mathrm{~V}$ vs. $\mathrm{Li}^{+} / \mathrm{Li}$, resulting in different theoretical gravimetric capacities of $131 \mathrm{mAh} \cdot \mathrm{g}^{-1}$ and $197 \mathrm{mAh} \cdot \mathrm{g}^{-1}$, respectively. ${ }^{18}$ The

*Electrochemical Society Member.

${ }^{\text {z} E-m a i l: ~ s . y u @ f z-j u e l i c h . d e ; ~ h . t e m p e l @ f z-j u e l i c h . d e ~}$ three-dimensional (3D) network of LVP is built from the slightly distorted $\mathrm{VO}_{6}$ octahedra and $\mathrm{PO}_{4}$ tetrahedra sharing oxygen vertexes (Fig. 1). Lithium atoms occupy three distinct crystallographic positions in the interstitial voids. As a result, the rate capability of LVP cathodes is much higher than that of many of the other cathode candidates due to its multi-lithium-ions diffusion pathways. ${ }^{21}$

Although many studies have investigated LVP cathodes in halfcells, ${ }^{22-27}$ few have also taken its full cell performance into account. Especially, its potential high rate capability has hardly been reached in full cells due to few equally well performing anode materials. For designing a full cell, $\mathrm{LiTi}_{2}\left(\mathrm{PO}_{4}\right)_{3}$ (LTP) can be considered as an outstanding anode candidate for LVP cathode because of its satisfactory theoretical capacity of $138 \mathrm{mAh} \cdot \mathrm{g}^{-1}$ and rapid $\mathrm{Li}^{+}$conductivity. ${ }^{19,28}$ LTP can reversibly accommodate two additional lithium-ions via a two-phase mechanism that converts between $\mathrm{LiTi}_{2}\left(\mathrm{PO}_{4}\right)_{3}$ and $\mathrm{Li}_{3} \mathrm{Ti}_{2}\left(\mathrm{PO}_{4}\right)_{3}$ at about $2.5 \mathrm{~V}$ vs. $\mathrm{Li}^{+} / \mathrm{Li}^{29,30} \mathrm{As}$ in the LVP material, the crystal structure of $\mathrm{LiTi}_{2}\left(\mathrm{PO}_{4}\right)_{3}$ consists of $\mathrm{PO}_{4}$ tetrahedra and $\mathrm{TiO}_{6}$ octahedra with large channels in the structure providing two types of interstitial sites (commonly referred to as M1 and M2) for lithium-ions as shown in Fig. 1. ${ }^{31,32}$ One of them (M1) is in the elongated octahedral oxygen environment at the intersection of three conduction channels, and the other (M2) is in an environment of 8-10 oxygen atoms at each bend of the conduction channels. Lithium-ions in $\mathrm{LiTi}_{2}\left(\mathrm{PO}_{4}\right)_{3}$ selectively occupy the M1 sites. Lithium intercalation in the material, however, is achieved by filling of the M2 cavities, which is associated with cooperative migration of $\mathrm{Li}^{+}$ions from the $\mathrm{M} 1$ to the $\mathrm{M} 2$ sites, till the $\mathrm{Li}_{3} \mathrm{Ti}_{2}\left(\mathrm{PO}_{4}\right)_{3}$ phase is eventually reached. The $\mathrm{LiTi}_{2}\left(\mathrm{PO}_{4}\right)_{3}$ framework is stable during $\mathrm{Li}^{+}$extraction and insertion that leads to long cycle life and safety performance. ${ }^{19,28}$ Although LTP has a relatively high voltage, the matching ability of LVP and LTP is still satisfactory due to their common outstanding performances of high ionic conductivity, low electrochemical expansion and shrinkage, high thermal stability, environmentally friendliness and mutually lithium-ion matching.

Despite of these advantages, lithium-transition-metal-phosphate electro-active materials suffer from intrinsically poor electronic conductivity $\left(10^{-8} \mathrm{~S} \cdot \mathrm{cm}^{-1}\right),{ }^{19,24}$ which strongly influences the electrochemical performance. Generally, there are different strategies to improve the electronic conductivity. In oxide materials, aliovalent doping has been demonstrated as an efficient means. ${ }^{33}$ An alternative approach is provided by controlled synthesis of these phosphate 

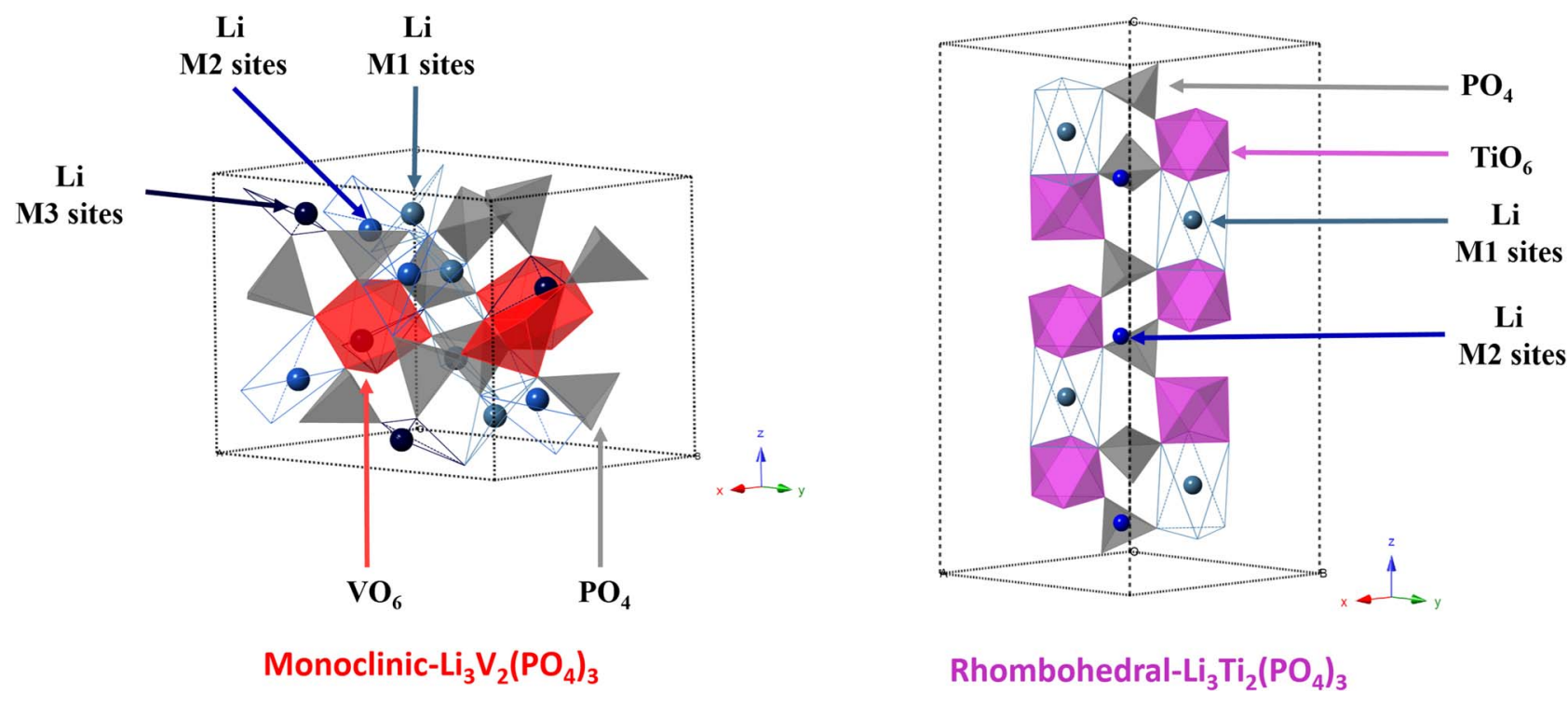

Figure 1. Part of the monoclinic $\mathrm{Li}_{3} \mathrm{~V}_{2}\left(\mathrm{PO}_{4}\right)_{3}$ and rhomobohedral $\mathrm{Li}_{3} \mathrm{Ti}_{2}\left(\mathrm{PO}_{4}\right)_{3}$ crystal structures showing the crystal sites of lithium atoms in the structures respectively.

materials with optimized particle size and morphology, ${ }^{19}$ as well as particle surface modification in terms of thin carbon layers. ${ }^{19,21-25}$ For this purpose, the solvothermal synthesis route offers additional flexibility in controlling morphology, grain size, and in-situ carbon coating and thus has been used for synthesizing transition metal phosphates like $\mathrm{LiFePO}_{4}, \mathrm{Li}_{3} \mathrm{~V}_{2}\left(\mathrm{PO}_{4}\right)_{3}$ and $\mathrm{LiTi}_{2}\left(\mathrm{PO}_{4}\right){ }^{34-40}$ The transition metal phosphate electrode materials with defined morphology and particle size prepared by solvothermal/hydrothermal methods provide a superior electrochemical performance compared to conventional preparation methods like solid-state reaction or sol-gel route. As reported, ${ }^{19}$ the spindle-like $\mathrm{LiTi}_{2}\left(\mathrm{PO}_{4}\right)_{3} / \mathrm{C}$ prepared by the solvothermal route shows a homogenous particle size, whereas the preparation via the sol-gel process results in agglomerated powders with irregular morphology and particle size. The different morphologies of LTP/Cs result in remarkable differences with respect to their electrochemical properties. The spindle-like LTP/C exhibits a capacity of $97.7 \%$ of its initial capacity which was maintained after 500 cycles at $5 \mathrm{C}$ indicating its superior rate capability and cycling stability.

In this work, an all phosphate lithium-ion battery with a high rate capability has been assembled based on spindle-like LTP/C and needle-like LVP/C. The specially designed morphologies of the electrodes bear the strain generated during charge-discharge to a great extent and thus lead to outstanding cycling stability. Additionally, the full cell can be conveniently assembled by adjusting the positive/negative capacity ratio, while the lithium-ions from the excess in the cathode can accommodate for the lithium loss during the formation of solid electrolyte interface (SEI) film on the surface of electrodes.

\section{Experimental}

Preparation of electrode materials.-All chemical reagents were purchased from Sigma-Aldrich and were used as received. Both $\mathrm{LiTi}_{2}\left(\mathrm{PO}_{4}\right)_{3} / \mathrm{C}$ and $\mathrm{Li}_{3} \mathrm{~V}_{2}\left(\mathrm{PO}_{4}\right)_{3} / \mathrm{C}$ electrode materials were prepared by solvothermal method in a commercial $500 \mathrm{ml}$ high-pressure reactor BR-300 (Berghof GmbH, Germany) with Teflon lining. The filling ratio for both synthesis reactions was controlled to be $70 \%$ of actual volume. The reaction conditions, including temperature and pressure, were recorded automatically and are shown in the Supplementary Information $\mathrm{S} 1$. For the $\mathrm{LiTi}_{2}\left(\mathrm{PO}_{4}\right)_{3} / \mathrm{C}$ anode material, the solvothermal method was followed by annealing process as detailed in the Supplementary Information and in our previous report. ${ }^{19}$ For the preparation of the solution precursor for the $\mathrm{Li}_{3} \mathrm{~V}_{2}\left(\mathrm{PO}_{4}\right)_{3} / \mathrm{C}$ cathode material, 0.05 mol ammonium metavanadate $\left(\mathrm{NH}_{4} \mathrm{VO}_{3}, \geq 99.0 \%\right)$ and oxalic acid $\left(\mathrm{H}_{2} \mathrm{C}_{2} \mathrm{O}_{4}, \geq 99.0 \%\right)$ in a stoichiometric ratio of 1:3 were first dissolved in a mixture of deionized water and ethanol (4:1 vol/vol) and afterwards magnetically stirred at $50^{\circ} \mathrm{C}$ for $12 \mathrm{~h}$ until a dark blue solution was formed. Stoichiometric amounts of lithium acetate dihydrate $\left(\mathrm{LiCOOCH}_{3} \cdot 2 \mathrm{H}_{2} \mathrm{O}, \geq 99.0 \%\right)$ and ammonium dihydrogenphosphate $\left(\mathrm{NH}_{4} \mathrm{H}_{2} \mathrm{PO}_{4}, \geq 99.999 \%\right)$ solutions were added slowly under continuous stirring. $3 \mathrm{wt} \%$ (in relation to the weight of all the solid materials) of hexadecyltrimethylammonium bromide (CTAB, $\geq 99 \%)$ surfactant was then dissolved in the prepared solution. The solution was then transferred into reactor and flushed with argon for 30 minutes in order to offer an inert environment to avoid side reactions of $\mathrm{V}^{4+}$. The asprepared Li-V-P-O-C precursor solution was transferred into a Teflon vessel. The reaction was kept at a temperature of $80^{\circ} \mathrm{C}$ for $3 \mathrm{~h}$, and the temperature was then subsequently increased to $180^{\circ} \mathrm{C}$ and held for $48 \mathrm{~h}$. The initial pressure was set to 50 bar by filling argon into the reactor vessel before the reaction was started. The stirring speed was set to $400 \mathrm{rpm}$ during the whole reaction process. After the reaction, the system was allowed to cool to room temperature. A stable wet Li-V-P-O-C powder precursor was obtained after centrifugation by Hettich Rotina 420/R centrifuge (Netherlands) at a speed of $8000 \mathrm{rpm}$ for 15 mins. Carbon-coated $\mathrm{Li}_{3} \mathrm{~V}_{2}\left(\mathrm{PO}_{4}\right)_{3}$ powders were obtained by annealing of the $\mathrm{Li}-\mathrm{V}-\mathrm{P}-\mathrm{O}-\mathrm{C}$ powder precursor at $800^{\circ} \mathrm{C}$ under $\mathrm{N}_{2}$ gas flow in a tube furnace for $8 \mathrm{~h}$.

Details of instrumental analysis. - The crystal structure and phase analysis was carried out using powder X-ray diffraction (XRD) measurements with an EMPYREAN (Panalytical, Netherlands) X-ray diffractometer with $\mathrm{Cu}-\mathrm{K} \alpha$ radiation, operating at $40 \mathrm{kV}, 40 \mathrm{~mA}$ and a scanning rate of $1^{\circ} \mathrm{min}^{-1}$ between $10^{\circ}$ and $70^{\circ}$. Scanning electron microscopy (SEM) images were taken using a Quanta FEG 650 (FEI, USA) environmental scanning electron microscope. Transmission electron microscopy (TEM) and high-resolution transmission electron microscopy (HRTEM) measurements were carried out by using a Tecnai F20 (FEI, USA) transmission electron microscope at an acceleration voltage of $200 \mathrm{kV}$. Raman spectra were recorded by a SENTERRA Raman microscope (Bruker, Germany) with an excitation wavelength of $532 \mathrm{~nm}$. The accumulation time was set to two minutes. Three spectra were obtained in sequence before each measurement to prevent photothermal damage of the sample. Thermogravimetric analysis (TGA) was performed on an NETZSCH TGA/STA-QMS 403D thermoanalyzer (Germany) between $40^{\circ} \mathrm{C}$ and $800^{\circ} \mathrm{C}$ with a heating rate of $3 \mathrm{~K} \mathrm{~min}^{-1}$ under $\mathrm{O}_{2}$ flow. The specific surface area was determined in Brunauer-Emmet-Teller (BET) 
Table I. Lattice parameters, grain size, carbon content and specific surface area of $\mathrm{LiTi}_{2}\left(\mathrm{PO}_{4}\right)_{3} / \mathrm{C}$ and $\mathrm{Li}_{3} \mathrm{~V}_{2}\left(\mathrm{PO}_{4}\right)_{3} / \mathrm{C}$.

\begin{tabular}{|c|c|c|c|c|c|c|c|c|c|c|c|}
\hline \multirow[b]{2}{*}{ Components } & \multicolumn{9}{|c|}{ Lattice parameters } & \multirow{2}{*}{$\begin{array}{c}\text { Carbon } \\
\text { content (wt\%) }\end{array}$} & \multirow{2}{*}{$\begin{array}{c}\text { Specific surface } \\
\text { area }\left( \pm 0.4 \mathrm{~g} \cdot \mathrm{m}^{-2}\right)\end{array}$} \\
\hline & $a(\AA)$ & $b(\AA)$ & $c(\AA)$ & $\alpha(\operatorname{deg})$ & $\beta(\operatorname{deg})$ & $\gamma(\operatorname{deg})$ & $V\left(\AA^{3}\right)$ & $R_{\mathrm{wp}}(\%)$ & $R_{\mathrm{p}}(\%)$ & & \\
\hline $\begin{array}{c}\operatorname{LiTi}_{2}\left(\mathrm{PO}_{4}\right)_{3} / \mathrm{C} \\
\text { Rhombohedral } R-3 \mathrm{c}\end{array}$ & 8.5129 & 8.5129 & 20.8780 & 90 & 90 & 120 & 1310.3 & 4.4 & 3.8 & 4.8 & 12.72 \\
\hline $\begin{array}{c}\mathrm{Li}_{3} \mathrm{~V}_{2}\left(\mathrm{PO}_{4}\right)_{3} / \mathrm{C} \\
\text { Monoclinic } P-2 / / \mathrm{n}\end{array}$ & 8.6095 & 8.6233 & 12.0614 & 90 & 90.0225 & 90 & 885.2 & 5.9 & 4.7 & 5.6 & 14.37 \\
\hline
\end{tabular}

measurements by $\mathrm{N}_{2}$ adsorption. For this, the automatic adsorption analyzer QUADRASORB evo (Quantachrome Instruments, USA) at liquid nitrogen temperature was used. The sample was degassed under vacuum with a Flowvac degasser (Quantachrome Instruments, USA) at $180^{\circ} \mathrm{C}$ for at least $20 \mathrm{~h}$ prior to data collection. With the used instrument, the reproducibility and accuracy of specific surface area results of the samples are $\pm 0.4 \mathrm{~m}^{2} \cdot \mathrm{g}^{-1}$ which has been investigated by the authors with different samples.

Cell assembly and electrochemical properties.-The electrochemical performance of the $\mathrm{LiTi}_{2}\left(\mathrm{PO}_{4}\right)_{3} / \mathrm{C}$ and $\mathrm{Li}_{3} \mathrm{~V}_{2}\left(\mathrm{PO}_{4}\right)_{3} / \mathrm{C}$ electrodes was investigated in Swagelok-type cells with an active area of $1.13 \mathrm{~cm}^{2}$. The working electrodes in half-cells were prepared by mixing active material $\left(\mathrm{LiTi}_{2}\left(\mathrm{PO}_{4}\right)_{3} / \mathrm{C}\right.$ or $\left.\mathrm{Li}_{3} \mathrm{~V}_{2}\left(\mathrm{PO}_{4}\right)_{3} / \mathrm{C}\right)$, carbon black (super $\mathrm{P}$ ) and polyvinylidene fluoride (PVDF, Sigma-Aldrich, Germany) binder in a weight ratio of 80:10:10 with subsequent tape casting (Zehntner, Switzerland) of the mixture on current collector (Al-foil for cathode, $\mathrm{Cu}$-foil for anode). The wet thickness of LTP/C anode was controlled to be $110 \mu \mathrm{m}$ while $140 \mu \mathrm{m}$ for the LVP/C cathode. Metallic lithium foil (Alfa-Aesar, Germany) was used as both counter and reference electrode. A glass fiber membrane served as separator and $1 \mathrm{M} \mathrm{LiPF}_{6}$ in a 1:1 solvent mixture of ethylene carbonate (EC)/dimethyl carbonate (DMC) (LP30, BASF, USA) was used as electrolyte.

To make a full cell, as prepared $\mathrm{LiTi}_{2}\left(\mathrm{PO}_{4}\right)_{3} / \mathrm{C}$ and $\mathrm{Li}_{3} \mathrm{~V}_{2}\left(\mathrm{PO}_{4}\right)_{3} / \mathrm{C}$ electrode were joint to the side of anode and cathode electrodes in Swagelok-type cells, respectively. The same type of LP30 electrolyte and glass fiber separator as for the half-cells was used. The assembly of all the test cells was carried out in an argon filled glove box, where the concentrations of water and oxygen were kept less than $0.1 \mathrm{ppm}$. The cell balance value (i.e. the capacity ratio of the anode to the cathode) is selected to be $1: 1.2$ to ensure the efficient utilization of the anode material. In order to prove the reproducibility of the electrochemical performance measurements, batches of five cells were measured for the half-cells and full cells. Cyclic voltammetry (CV), electrochemical impedance spectroscopy (EIS) and galvanostatic charge/discharge measurements for all the cells were conducted using a VMP3 potentiostat (Bio-Logic, France). The performed electrochemical tests were carried out at $25^{\circ} \mathrm{C}$ in a climate chamber MKF120 (Binder, Germany).

\section{Results and Discussion}

The X-ray diffraction (XRD) patterns of LTP/C and LVP/C prepared by solvothermal method at various annealing temperatures are shown in Supplementary Information (S2), from which it can be seen that all of the synthesized LTP/C materials show a rhombohedral structure (space group $R-3 c$, ICSD No. 95979) while the LVP/C materials show a monoclinic structure (space group $P 2_{1} / \mathrm{n}$, ICSD No. 167238). Moreover, all diffraction peaks of LTP/C and LVP/C specimens annealed at $800^{\circ} \mathrm{C}$ are indexed to the pure LTP and LVP phase, demonstrating the optimal annealing temperature for obtaining high purity LTP/C and LVP/C samples. Hence, all of the further experiments are carried out by using the LTP/C and LVP/C samples specifically annealed at $800^{\circ} \mathrm{C}$. As shown in Table I and Fig. 2a and $2 \mathrm{~d}$, the lattice parameter values for LTP/C and LVP/C both annealed at $800^{\circ} \mathrm{C}$ were calculated from Rietveld refinement of the XRD patterns which are close to the literature values $(a=8.511 \AA, c=20.843$ $\AA$, ICSD 95979 for $\operatorname{LiTi}_{2}\left(\mathrm{PO}_{4}\right)_{3} / \mathrm{C} ; a=8.5978 \AA, b=8.5933 \AA$, $c=12.0327 \AA$, ICSD 167238 for $\left.\mathrm{Li}_{3} \mathrm{~V}_{2}\left(\mathrm{PO}_{4}\right)_{3} / \mathrm{C}\right)$. In the table, $R_{\text {wp }}$ is $\mathrm{R}$-weighted pattern and $R_{\mathrm{p}}$ is $\mathrm{R}$-pattern. Both of the $R$ values revealed the good fitting for LTP/C and LVP/C, respectively. The morphological features of LTP/C and LVP/C were examined by scanning electron microscopy (SEM), as shown in Fig. 2. Recognizable is the difference in morphology between the samples of the different materials which is intended. It can be clearly seen that the LTP/C anode material, in Fig. 2b, has a regular shape and the particulate sizes are homogeneously distributed. The agglomerates are mainly composed of spindle-like microstructures, out of small particles with lengths ranging from 6 to $10 \mu \mathrm{m}$ as shown in Fig. 2c. The LVP/C cathode material shows a nano-needle-like morphology (Fig. 2e and 2f) with a diameter of a single needle structure ranging from $300 \mathrm{~nm}$ to $500 \mathrm{~nm}$ and a length between $5 \mu \mathrm{m}$ and $7 \mu \mathrm{m}$. The special morphologies of LTP/C and LVP/C obtained by solvothermal reactions guarantee relatively large specific surface areas of the electrode materials (12.72 \pm $0.4 \mathrm{~g} \cdot \mathrm{m}^{-2}$ for LTP/C and $14.37 \pm 0.4 \mathrm{~g} \cdot \mathrm{m}^{-2}$ for LVP/C) as shown in Table I and Supplementary Information (S3). In principle, larger surface area of active materials shortens the electron and ion migration pathways and increases the contact areas between electrolyte and electrode which benefits the electrochemical performance, especially the rate capability. ${ }^{19}$

To investigate the morphology of the carbon layers on the LTP/C and LVP/C materials, high-resolution transmission electron microscopy (HR-TEM) was applied (Fig. 3). The spindle-like microstructured LTP/C, as well as the nano-needle-like LVP/C, as seen in the SEM, are clearly revealed as shown in Fig. 3a and 3d, respectively. HRTEM reveals the crystallinity of the particle with lattice planes visible, which can be indexed as $\{120\}$, for LTP in Fig. $3 b$ and $\{012\}$ for LVP in Fig. 3e. Also the amorphous carbon coating with thickness of about $4 \mathrm{~nm}$ for LTP/C and $3 \mathrm{~nm} \mathrm{LVP/C} \mathrm{can} \mathrm{be} \mathrm{rec-}$ ognized. LVP/C showed a clustered, bicontinuous (LVP and carbon) needle-like nanostructure with a uniformly carbon covered surface, as can be seen in Fig. 3 and S4 (Supplementary Information). This kind of sheaf-like structure is believed to be beneficial to the electrochemical performance by the means of improvement of both electronic and ionic conductivities. $^{26,41}$

In order to estimate the amount of carbon present in LTP/C and LVP/C, TGA was carried out by heating the samples under $\mathrm{O}_{2}$ flow. As shown in Fig. $3 \mathrm{c}$ and 3f, the gradual weight losses below $370^{\circ} \mathrm{C}$ in both samples are due to the evaporation of absorbed and chemically bonded water in the structures. The weight losses between $370^{\circ} \mathrm{C}$ and $530^{\circ} \mathrm{C}$ are attributed to the combustion of residual carbon, ${ }^{42}$ indicating that the carbon content is $4.8 \mathrm{wt} \%$ in the LTP/C material and 5.6 wt\% in the LVP/C. In addition, the carbon content was estimated by dissolving the LTP/C and LVP/C sample in hydrochloric acid using ultrasonic cell disruptor. The undissolved residues were weighed using a microbalance and were found to be $4.3 \mathrm{wt} \%$ for LTP/C and $5.3 \mathrm{wt} \%$ for $\mathrm{LVP} / \mathrm{C}$, which is in accordance with the TGA results. Raman spectroscopy was applied to characterize the surface carbon layer of the LTP/C and LVP/C particles (Supplementary Information S5). The existence of carbon with its two characteristic bands at $\sim 1370 \mathrm{~cm}^{-1}$ and $\sim 1590 \mathrm{~cm}^{-1}$ was observed in both samples, revealing pronounced features characteristic for disordered carbon (D-band) and graphitic structure (G-band). The disordered carbon on the surface of LVP and LTP may help to bind the active materials to the conductive agent of carbon black in the electrode and thus improve the bonding of electrode layers and substrates, whereas the graphitic structured 

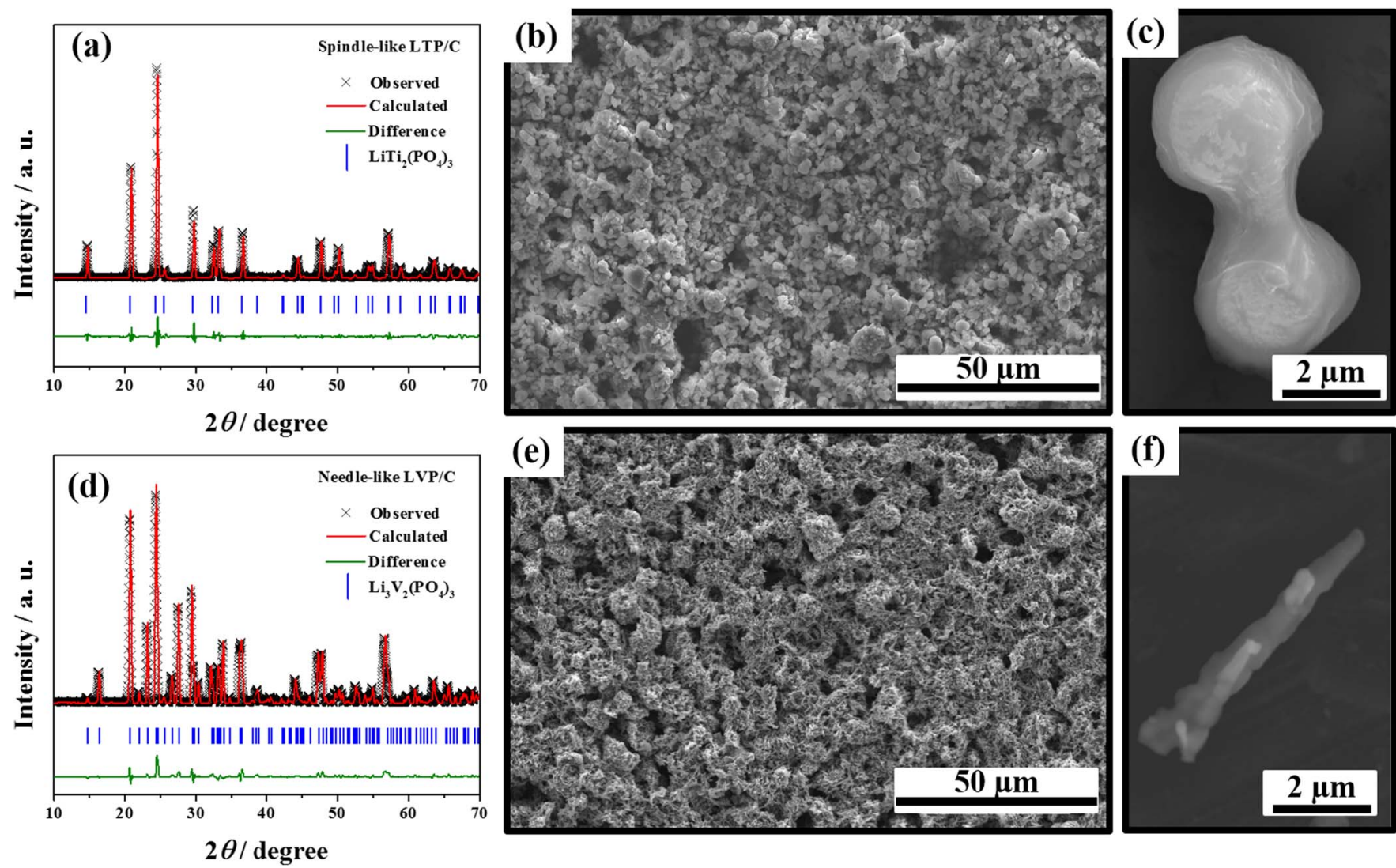

Figure 2. Powder XRD diffraction pattern of (a) $\mathrm{LiTi}_{2}\left(\mathrm{PO}_{4}\right)_{3} / \mathrm{C}$ and (d) $\mathrm{Li}_{3} \mathrm{~V}_{2}\left(\mathrm{PO}_{4}\right)_{3} / \mathrm{C}$ indicating high phase purity of prepared samples. SEM images of $\mathrm{LiTi}_{2}\left(\mathrm{PO}_{4}\right)_{3} / \mathrm{C}((\mathrm{b})$ and $(\mathrm{c}))$ with spindle-like morphology, and $\mathrm{Li}_{3} \mathrm{~V}_{2}\left(\mathrm{PO}_{4}\right)_{3} / \mathrm{C}((\mathrm{e})$ and (f)) with nanoneedle-like morphology.
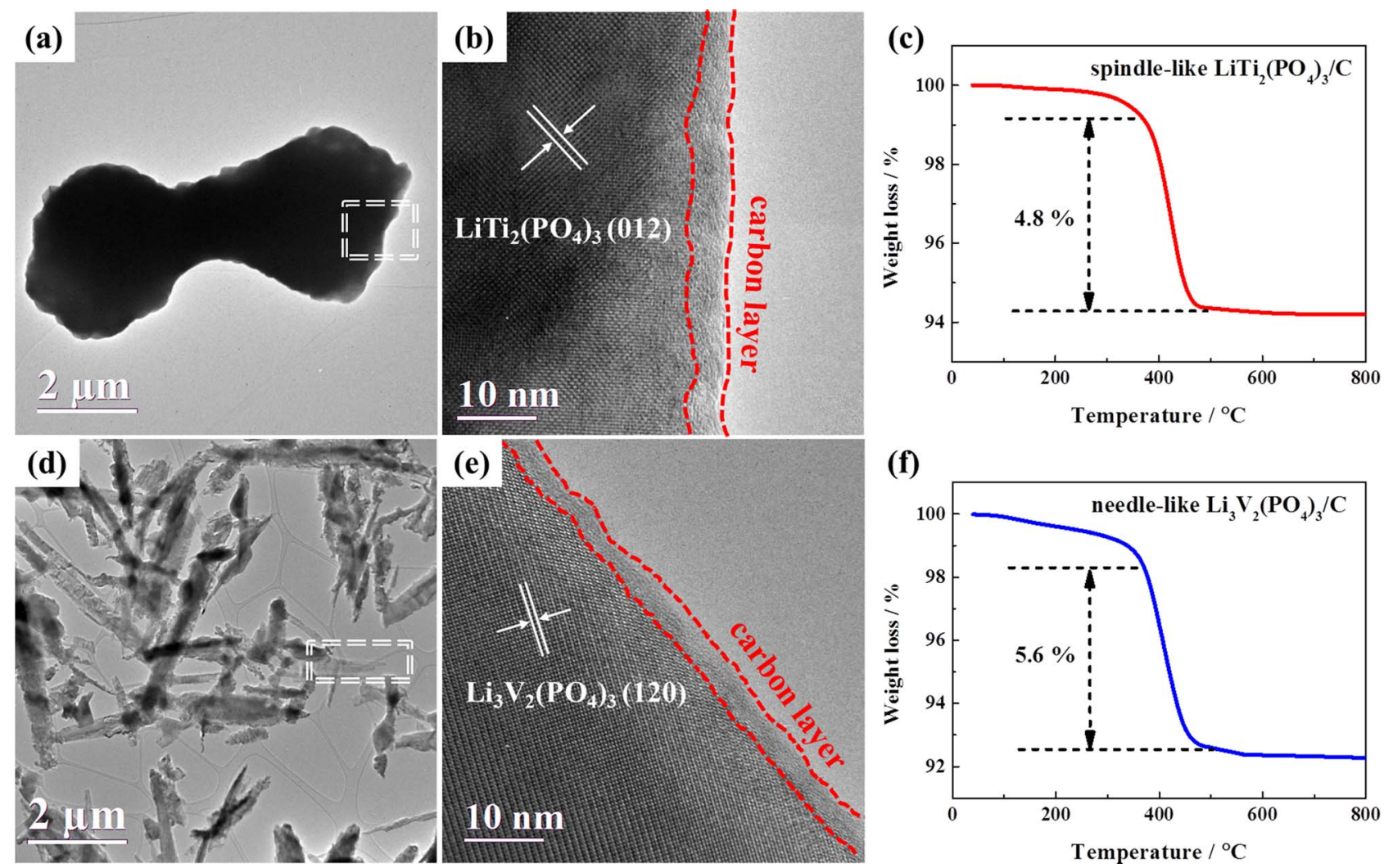

Figure 3. TEM and HR-TEM images of $\mathrm{LiTi}_{2}\left(\mathrm{PO}_{4}\right)_{3} / \mathrm{C}((\mathrm{a})$ and $(\mathrm{b}))$ and $\mathrm{Li}_{3} \mathrm{~V}_{2}\left(\mathrm{PO}_{4}\right)_{3} / \mathrm{C}((\mathrm{d})$ and (e)) with the observation of carbon layer on the surface of each sample. TGA curves for evaluating carbon amount of $\mathrm{LiTi}_{2}\left(\mathrm{PO}_{4}\right)_{3} / \mathrm{C}$ (c) and $\mathrm{Li}_{3} \mathrm{~V}_{2}\left(\mathrm{PO}_{4}\right)_{3} / \mathrm{C}$ (f). 
(a) Voltage / V

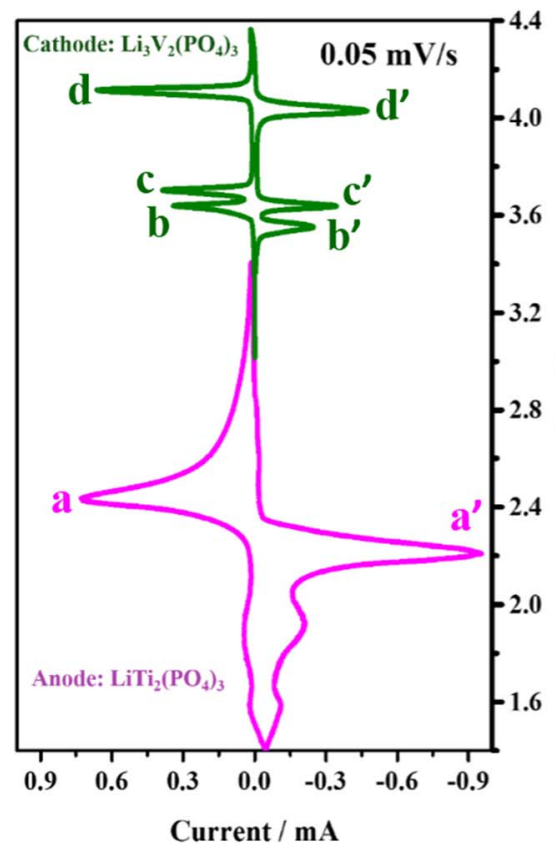

(b)

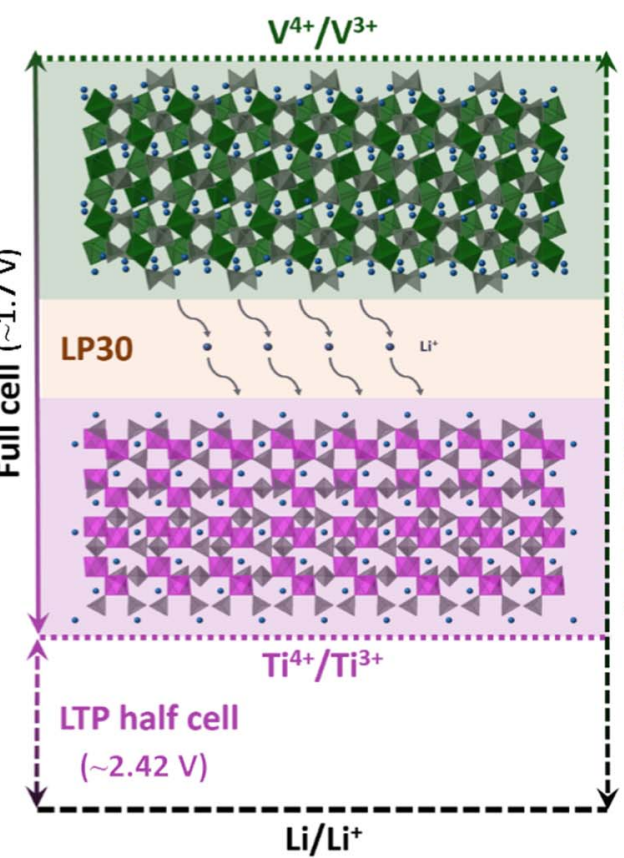

(c)

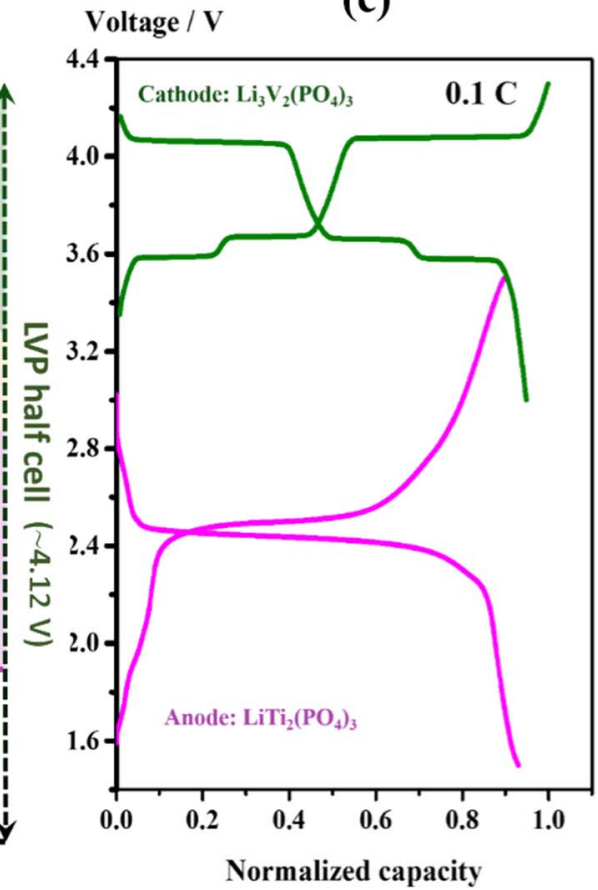

Figure 4. (a) The cyclic voltammetry profile of the $\mathrm{LiTi}_{2}\left(\mathrm{PO}_{4}\right)_{3} / \mathrm{C}$ electrode in the voltage range of $1.5-3.5 \mathrm{~V}$ and the $\mathrm{Li}_{3} \mathrm{~V}_{2}\left(\mathrm{PO}_{4}\right)_{3} / \mathrm{C}$ electrode in the voltage range of 3.0-4.4 V vs. $\mathrm{Li}^{+} / \mathrm{Li}$. (b) Structural schematic of the battery's active materials. (c) Charge-discharge profiles of the $\mathrm{LiTi}_{2}\left(\mathrm{PO}_{4}\right)_{3} / \mathrm{C}$ electrode in the voltage range of 1.5-3.5 $\mathrm{V}$ and the $\mathrm{Li}_{3} \mathrm{~V}_{2}\left(\mathrm{PO}_{4}\right)_{3} / \mathrm{C}$ electrode in the voltage range of 3.0-4.4 $\mathrm{V} \mathrm{vs.} \mathrm{Li}^{+} / \mathrm{Li}$.

carbon is necessary for the improvement of electronic conductivity of active materials. ${ }^{19,26-29,35-38}$ In combination with the information obtained from HR-TEM and TGA, it can be concluded that both of the specimens contain a layer of conductive carbon. The coated carbon on phosphate materials can influence on the electrochemical performance by means of improvement of electronic conductivity as well as the formation of SEI layer. ${ }^{13}$

The electrochemical characteristics of the $\mathrm{LiTi}_{2}\left(\mathrm{PO}_{4}\right)_{3} / \mathrm{C}$ and $\mathrm{Li}_{3} \mathrm{~V}_{2}\left(\mathrm{PO}_{4}\right)_{3} / \mathrm{C}$ electrodes were assessed in half-cells vs. $\mathrm{Li}^{+} / \mathrm{Li}$ Fig. $4 \mathrm{a}$ and $4 \mathrm{c}$ show cyclic voltammetry $(\mathrm{CV})$ curves and initial charge-discharge curves of these. The CV curve of LTP/C is obtained at a potential scanning rate of $0.05 \mathrm{mV} \cdot \mathrm{s}^{-1}$ in the potential window $1.5 \sim 3.5 \mathrm{~V}$ (vs. $\mathrm{Li}^{+} / \mathrm{Li}$ ), as shown in Fig. 4a. It clearly shows the main oxidation-reduction reactions at $2.45 \mathrm{~V}$ and $2.21 \mathrm{~V}$, characteristic for $\mathrm{LiTi}_{2}\left(\mathrm{PO}_{4}\right)_{3}$. Rhombohedral $\mathrm{LiTi}_{2}\left(\mathrm{PO}_{4}\right)_{3}$ can intercalate up to two lithium-ions reversibly which is accompanied by the oxidation-reduction process $\mathrm{Ti}(\mathrm{IV}) / \mathrm{Ti}(\mathrm{III})$.

$$
\begin{gathered}
\mathrm{Li}_{3} \mathrm{Ti}_{2}\left(\mathrm{PO}_{4}\right)_{3} \rightarrow \mathrm{LiTi}_{2}\left(\mathrm{PO}_{4}\right)_{3}+2 \mathrm{Li}^{+}+2 \mathrm{e}^{-} \\
\mathrm{LiTi}_{2}\left(\mathrm{PO}_{4}\right)_{3}+2 \mathrm{Li}^{+}+2 \mathrm{e}^{-} \rightarrow \mathrm{Li}_{3} \mathrm{Ti}_{2}\left(\mathrm{PO}_{4}\right)_{3}
\end{gathered}
$$

The current peak at about $2.45 \mathrm{~V}$ (a) corresponds to the oxidation of $\mathrm{Ti}(\mathrm{III})$ to $\mathrm{Ti}(\mathrm{IV})$, which is assigned to the electrochemical delithiation process (Equation 1), and the current peak at about $2.2 \mathrm{~V}$ (a') corresponds to the reduction of $\mathrm{Ti}(\mathrm{IV})$ to $\mathrm{Ti}(\mathrm{III})$, which is assigned to the electrochemical lithiation process (Equation 2). For the oxidation reaction as described in Equation 1, two lithium-ions de-insert from $\mathrm{Li}_{3} \mathrm{Ti}_{2}\left(\mathrm{PO}_{4}\right)_{3}$ accompanied by the charge compensation. As a result, $\mathrm{Ti}(\mathrm{III})$ is oxidized to $\mathrm{Ti}(\mathrm{IV})$ and the $\mathrm{LiTi}_{2}\left(\mathrm{PO}_{4}\right)_{3}$ phase is formed. For the reduction reaction, Ti(IV) is reduced to Ti(III) by the reverse process (Equation 2). In general, as shown in Fig. 1, since Li-ions occupy the M1 sites in $\mathrm{LiTi}_{2}\left(\mathrm{PO}_{4}\right)_{3}$, the lithium exchange takes place in onestep due to the insertion of lithium-ions into the vacant M2 sites and the subsequent cooperative migration of lithium-ions from M1 to M2 sites. ${ }^{19}$ However, as can be seen in the CV curve of LTP/C half-cell, there are broad oxidation-reduction peaks at about $1.8 \mathrm{~V}$ which may due to the variation in the occupancy of Li-ion and/or disordering of Li-ion along $c$-axis caused by the interaction of spindle-like morphology and expanded $c$-axis (shown in Table I). This is in agreement, with the change of the $c$-axis, which has been found and can be a result of vacancies on the M1 site. ${ }^{19,43}$ The voltage profile for a dischargecharge cycle of $\mathrm{LTP} / \mathrm{C}$ from 1.5 to $3.5 \mathrm{~V}$ vs. $\mathrm{Li}^{+} / \mathrm{Li}$ at a current density of $0.1 \mathrm{C}$ can be seen in the right side of Fig. $4 \mathrm{c}$. The charge-discharge curve displays a reversible, distinct plateau of $2.45 \mathrm{~V}$, which agrees well with the $\mathrm{CV}$ curve. The normalized capacity is given by the ratio between the discharge capacity of LTP/C and its theoretical capacity $\left(\sim 92.5 \%\right.$ of $\left.138 \mathrm{mAh} \cdot \mathrm{g}^{-1}\right)$.

The potential scanning rate of the CV measurement (Fig. 4a) for $\mathrm{LVP} / \mathrm{C}$ was $0.05 \mathrm{mV} \cdot \mathrm{s}^{-1}$ in the potential window of 3.0 to $4.4 \mathrm{~V}$ (vs. $\left.\mathrm{Li}^{+} / \mathrm{Li}\right)$. The oxidation and reduction peaks indicating the reversible extraction/insertion of lithium-ions from/into $\mathrm{Li}_{3} \mathrm{~V}_{2}\left(\mathrm{PO}_{4}\right)_{3}$. During the oxidation process, three well-defined oxidation peaks are observed at $\sim 3.60 \mathrm{~V}(\mathrm{~b}), \sim 3.69 \mathrm{~V}$ (c) and $\sim 4.10 \mathrm{~V}(\mathrm{~d})\left(\mathrm{vs} . \mathrm{Li}^{+} / \mathrm{Li}\right)$ for all LVP/C specimens. The peaks at $\sim 3.60 \mathrm{~V}$ and $\sim 3.69 \mathrm{~V}$ are associated with the phase transitions of $\mathrm{Li}_{3} \mathrm{~V}_{2}\left(\mathrm{PO}_{4}\right)_{3}$ to $\mathrm{Li}_{2.5} \mathrm{~V}_{3}\left(\mathrm{PO}_{4}\right)_{3}$ (Equation 3) and $\mathrm{Li}_{2.5} \mathrm{~V}_{3}\left(\mathrm{PO}_{4}\right)_{3}$ to $\mathrm{Li}_{2} \mathrm{~V}_{3}\left(\mathrm{PO}_{4}\right)_{3}$ (Equation 4 ), respectively. The peak located at $\sim 4.10 \mathrm{~V}$ is related to the delithiation of the second lithium-ion to form $\mathrm{LiV}_{2}\left(\mathrm{PO}_{4}\right)_{3}$ (Equation 5). The reduction peaks at $\sim 3.54 \mathrm{~V}$ (b'), $\sim 3.62 \mathrm{~V}$ (c') and $\sim 4.04 \mathrm{~V}$ (d') in the subsequent reduction process are identified as the reverse process of the insertion of lithium-ions into the $\mathrm{LiV}_{2}\left(\mathrm{PO}_{4}\right)_{3}$.

$$
\begin{gathered}
\mathrm{Li}_{3} \mathrm{~V}_{2}\left(\mathrm{PO}_{4}\right)_{3} \leftrightarrow \mathrm{Li}_{2.5} \mathrm{~V}_{2}\left(\mathrm{PO}_{4}\right)_{3}+0.5 \mathrm{Li}^{+}+0.5 \mathrm{e}^{-} \\
\mathrm{Li}_{2.5} \mathrm{~V}_{2}\left(\mathrm{PO}_{4}\right)_{3} \leftrightarrow \mathrm{Li}_{2} \mathrm{~V}_{2}\left(\mathrm{PO}_{4}\right)_{3}+0.5 \mathrm{Li}^{+}+0.5 \mathrm{e}^{-} \\
\mathrm{Li}_{2} \mathrm{~V}_{2}\left(\mathrm{PO}_{4}\right)_{3} \leftrightarrow \mathrm{LiV}_{2}\left(\mathrm{PO}_{4}\right)_{3}+\mathrm{Li}^{+}+\mathrm{e}^{-}
\end{gathered}
$$

The corresponding discharge-charge profile of LVP/C is displayed in Fig. 4c, and the apparent steps correspond to these found in the $\mathrm{CV}$ curve. The capacity of LVP/C obtained at $0.1 \mathrm{C}$ is $\sim 95.4 \%$ of its theoretical capacity $\left(133 \mathrm{mAh} \cdot \mathrm{g}^{-1}, 3.0-4.3 \mathrm{~V}, \mathrm{vs} . \mathrm{Li}^{+} / \mathrm{Li}\right)$. The 
detailed electrochemical performances of LTP/C and LVP/C in halfcells including the rate capability and cycle stability are investigated subsequently. Fig. $4 \mathrm{~b}$ shows the schematic of the working potential of the $\mathrm{V}^{4+} / \mathrm{V}^{3+}$ redox couple vs. $\mathrm{Li}^{+} / \mathrm{Li}$ in monoclinic $\mathrm{Li}_{3} \mathrm{~V}_{2}\left(\mathrm{PO}_{4}\right)_{3}$ and $\mathrm{Ti}^{4+} / \mathrm{Ti}^{3+}$ redox couples vs. $\mathrm{Li}^{+} / \mathrm{Li}$ in rhombohedral $\mathrm{LiTi}_{2}\left(\mathrm{PO}_{4}\right)_{3}$. The average charge potential of the asymmetric cell based on the LVP/C cathode and LTP/C anode is predicted on the basis of their voltage difference, shown in Fig. 4b. Although the potential of LTP/C//LVP/C is relatively low $(\sim 1.7 \mathrm{~V})$, there are still demands for such kind of low-voltage batteries both in market and research community. For instance, it can meet the requirements of monolithic integration of a thin-film solar cell and lithium-ion battery. ${ }^{44,45}$ And the superior rate capability of the LTP/C//LVP/C battery, which will be mentioned below, offers an opportunity for the improvement of the integration of lithium-ion battery and solar cell. Importantly, the mutually matched theoretical capacity of LVP/C and LTP/C allows a high freedom to choose the limited electrode and the ratio of two electrodes in full cell. In this work, to make full use of the anode material as well as to decrease the effects of Li loss during the first cycle in the full cell, the capacity ratio of LTP/C and LVP/C was selected to be about 1:1.2 and thus the full cell is an anode-limited cell. In the subsequent part, the electrochemical performances of LTP/C anode and LVP/C will be evaluated in half-cells in detail and the electrochemical behaviors of limited anode LTP/C//LVP/C full cell will be represented.

The electrochemical performances of the $\mathrm{LiTi}_{2}\left(\mathrm{PO}_{4}\right)_{3} / \mathrm{C} / / \mathrm{Li}$ and $\mathrm{Li}_{3} \mathrm{~V}_{2}\left(\mathrm{PO}_{4}\right)_{3} / \mathrm{C} / / \mathrm{Li}$ half-cells were investigated as feasibility test for a $\mathrm{LiTi}_{2}\left(\mathrm{PO}_{4}\right)_{3} / \mathrm{C} / / \mathrm{Li}_{3} \mathrm{~V}_{2}\left(\mathrm{PO}_{4}\right)_{3} / \mathrm{C}$ full cell. Fig. 5a shows the chargedischarge profiles of the half-cells at $0.1 \mathrm{C}$ for the second, third and fourth cycles. The profiles of the LTP/C half-cell showed chargedischarge voltage plateaus at about $2.49 \mathrm{~V}$ and $2.44 \mathrm{~V}$, respectively. The discharge capacities of the LTP/C half-cell were $134.1 \mathrm{mAh} \cdot \mathrm{g}^{-1}$, $132.0 \mathrm{mAh} \cdot \mathrm{g}^{-1}$ and $130.5 \mathrm{mAh} \cdot \mathrm{g}^{-1}$ for the $2^{\text {nd }}, 3^{\text {rd }}$ and $4^{\text {th }}$ cycle, respectively. In the case of the $\mathrm{Li}_{3} \mathrm{~V}_{2}\left(\mathrm{PO}_{4}\right)_{3} / \mathrm{C} / / \mathrm{Li}$ half-cell, three reversible discharge voltage plateaus at around $4.06 \mathrm{~V}, 3.66 \mathrm{~V}$ and $3.57 \mathrm{~V}$, and charge voltage plateaus at around $3.58 \mathrm{~V}, 3.67 \mathrm{~V}$ and 4.08 $\mathrm{V}$ were revealed. The discharge capacities of the LVP/C half-cell for the $2^{\text {nd }}, 3^{\text {rd }}$ and $4^{\text {th }}$ cycle were $125.1 \mathrm{mAh} \cdot \mathrm{g}^{-1}, 123.9 \mathrm{mAh} \cdot \mathrm{g}^{-1}$ and $122.3 \mathrm{mAh} \cdot \mathrm{g}^{-1}$ respectively. Concluding, the anode and cathode materials showed superior capability at low current densities in comparison with their theoretical capacities.

The rate performance of the LTP/C and LVP/C half-cells was further compared for the subsequent cycles as shown in Fig. 5b. After rapid changes of the current rate, all the prepared electrodes show stable capacities at each state. With the current rate increasing, the LTP/C electrode exhibits higher rate capability as compared to state of the art. ${ }^{46-48}$ A discharge capacity of $\sim 18 \mathrm{mAh} \cdot \mathrm{g}^{-1}$ (10.1\% of theoretical capacity) was still delivered even at a current density of 100 C. When the cycling rate is reduced to $0.1 \mathrm{C}$ again, about $97.4 \%$ of the initial capacity of the LTP/C electrode was recovered. Although the capacities of the LVP/C half-cell at $0.1 \mathrm{C}$ were lower than that of the LTP/C electrode, a better high rate capability was achieved. There is only slight capacity fading for the LVP/C electrode with increasing current density from $0.1 \mathrm{C}$ to $10 \mathrm{C}$, and around $25 \%$ of its theoretical capacity could be delivered at $100 \mathrm{C}$ which is almost two times of the delivered capacity of the LTP/C electrode. When the current density was decreased from $100 \mathrm{C}$ to $0.1 \mathrm{C}$ at the end of cycling, the discharge capacity of the LVP/C//Li half-cell still reached $125.3 \mathrm{mAh} \cdot \mathrm{g}^{-1}$, which is $98.3 \%$ of its initial capacity. As for a battery of automotive applications, a maximum of $7 \mathrm{C}$ is required. The excellent rate capability of LTP/C and LVP/C define good candidate as electrode materials.

The cycling performances of the LTP/C and LVP/C half-cells at a current rate of $0.5 \mathrm{C}$ are shown in Fig. $5 \mathrm{c}$ and $5 \mathrm{~d}$. Both electrodes showed stable discharge capacities up to 200 cycles. The LTP/C//Li half-cell delivered $115.0 \mathrm{mAh} \cdot \mathrm{g}^{-1}$ with a capacity retention of $96.9 \%$ and the LVP/C half-cell delivered $118.1 \mathrm{mAh} \cdot \mathrm{g}^{-1}$ which is $97.5 \%$ of its initial discharge capacity. The results indicate the excellent cycling stability at low current density of the prepared half-cells. Furthermore, the electrochemical behavior of LTP/C and LVP/C half-cells before and after 200 cycles was investigated by electrochemical impedance spectroscopy (EIS) in the frequency range from $100 \mathrm{kHz}$ to $10 \mathrm{mHz}$. As shown in Fig. 5e and 5f, all Nyquist plots of the cells exhibit a semicircle in the high-frequency region which is ascribed to chargetransfer processes of the lithium-ion through the interface from the surface layer of the particles to the electrolyte. In addition, a straight line appeared in the low-frequency region which is associated with solid-state diffusion. ${ }^{49}$ After 200 cycles, the charge-transfer resistances of the prepared half-cells showed only a slight decrease. This result is in accordance with the good cycling stability and hints at the structural and electrical integrity of the electrodes and their interfaces with the electrolyte during cycling.

The superior rate capability and cycling stability of the prepared half-cells were obtained due to the special designed morphology of the active materials as has been described in the former work. ${ }^{19}$ Specifically, the spindle-like LTP/C agglomerates which formed during solvothermal reaction at high pressure and high temperature effectively withstand long-term mechanical strain owing to volume changes during cycling. And the uniform and small agglomerates of spindlelike LVP/C offer better contact between anode material and electrolyte, and thus lead to favorable electrochemical performance at high current densities. In the case of LVP/C, its bicontinuous needlelike nanostructure with a uniformly carbon-covered surface provides (a) continuous channels of carbon to guaranty the electronic conductivity; (b) effective pathways along/across the needle-like LVP for $\mathrm{Li}^{+}$ extraction/reinsertion to ensure the ionic conductivity; (c) relatively high specific surface area that allows sufficient contact area between the liquid electrolyte and the electrode. These features of the prepared LVP/C provide the basis for its superior electrochemical high-rate capability.

Fig. 6a shows the $\mathrm{CV}$ profiles at a scanning rate of $0.03 \mathrm{mV} \cdot \mathrm{s}^{-1}$ of a full cell assembled by the prepared $\mathrm{LiTi}_{2}\left(\mathrm{PO}_{4}\right)_{3} / \mathrm{C}$ and $\mathrm{Li}_{3} \mathrm{~V}_{2}\left(\mathrm{PO}_{4}\right)_{3} / \mathrm{C}$ electrodes. Comparing the first $\mathrm{CV}$ scan of full cell and the $\mathrm{CV}$ results of half-cells shown in Fig. $4 \mathrm{a}$, four redox couple peaks in the voltage range of 0.5 to $2.2 \mathrm{~V}$ can be attributed to two lithium-ions deintercalated/intercalated from/into LVP/C into/from LTP/C. However, there are apparently redox peaks shifts and one redox couple (peaks (b) and (b')) was missing for the following CV scans of the full cell. These could be due to the formation of the SEI and irreversible changes at high voltage in the electrodes. The spontaneously and electrochemically formation of SEI in lithium transition-metal phosphate electrodes during first cycle has been proved attribute to the carbon additive in the electrode composition but not the phosphate materials. ${ }^{13}$ Hence, the second, fifth and tenth CV profiles in Fig. 6a were in good agreement with each other indicating high reversibility of the lithiation and delithiation processes of the full cell. Therefore, we have chosen the working potential of the LTP/C//LVP/C full cell as 0.5 to $2.2 \mathrm{~V}$. The capacity loss due to the formation of the SEI can be seen in the first cycle of rate capability results of the full cell, also. The specific capacity was calculated according the quality of LTP/C due to its limited mass loading. As shown in Fig. 6b, the low first cycle coulombic efficiency of $\sim 68 \%$ quickly increases to more than $93 \%$ after the first cycle. Furthermore, the LTP/C//LVP/C full cell also exhibits high capacity at higher rates as shown in Fig. 6b. The full cell was charged/discharged at various current densities from $0.1 \mathrm{C}$ to $30 \mathrm{C}$ rate, for five cycles at each state. The stabilized discharge capacities of $115,95,85,66$ and $32 \mathrm{mAh} \cdot \mathrm{g}^{-1}$ were delivered at corresponding current densities. The discharge capacity can be recovered to $101 \mathrm{mAh} \cdot \mathrm{g}^{-1}$ when the rate was turned back to $0.1 \mathrm{C}$, and the value is basically consistent with that of capacity tested inconstant $\mathrm{C}$ rate in Fig. 6c. Fig. 6c shows the cycling performance and corresponding coulombic efficiency tested at a rate of $0.1 \mathrm{C}$. In contrast to most of the full cells with one layered electrode, the LTP/C//LVP/C full cell has two electrodes which exhibit phase transitions during cycling. As a consequence, the discharge capacity of LTP/C//LVP/C full cell is fading during the first 20 cycles from $123.9 \mathrm{mAh} \cdot \mathrm{g}^{-1}$ down to $99.2 \mathrm{mAh} \cdot \mathrm{g}^{-1}$ and then tend to stabilize for the rest of the cycles. A discharge capacity of $90.2 \mathrm{mAh} \cdot \mathrm{g}^{-1}$ with a capacity retention of $\sim 73 \%$ after 100 cycles is obtained. The charge-discharge curves 
(a)

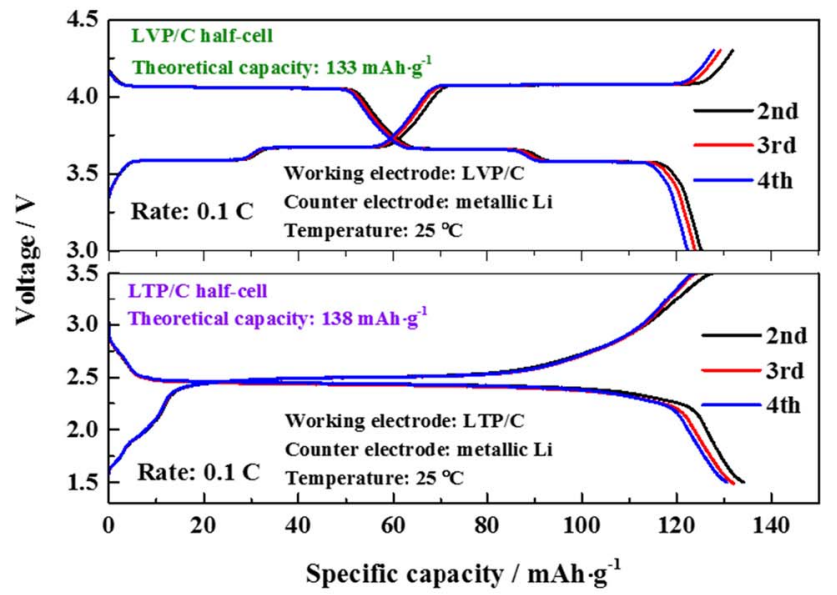

(c)

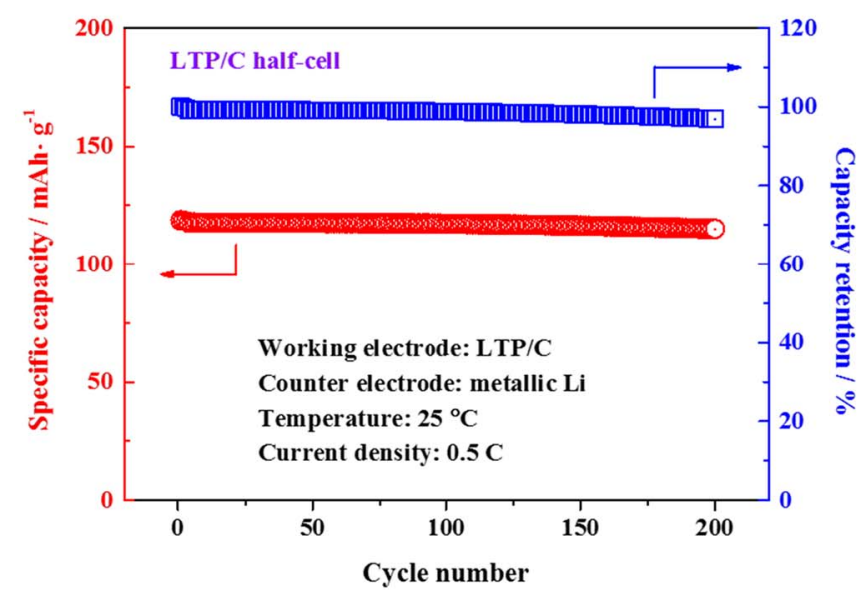

(e)

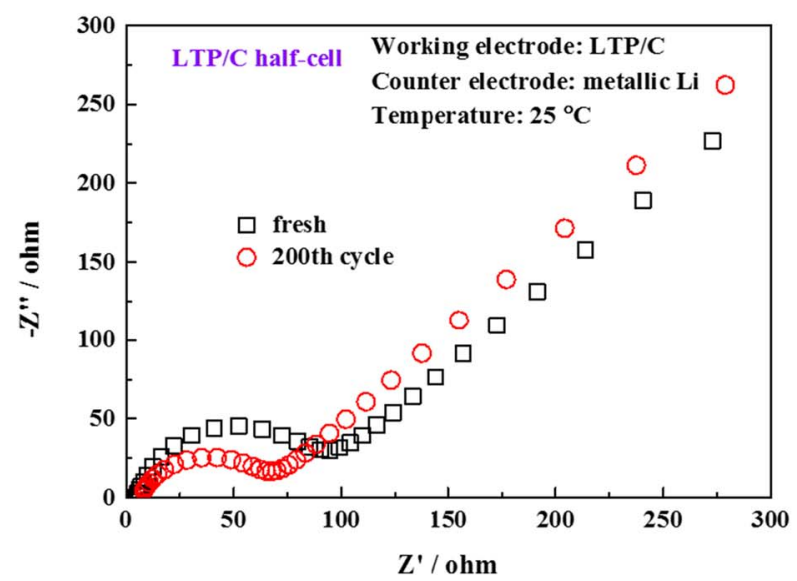

(b)

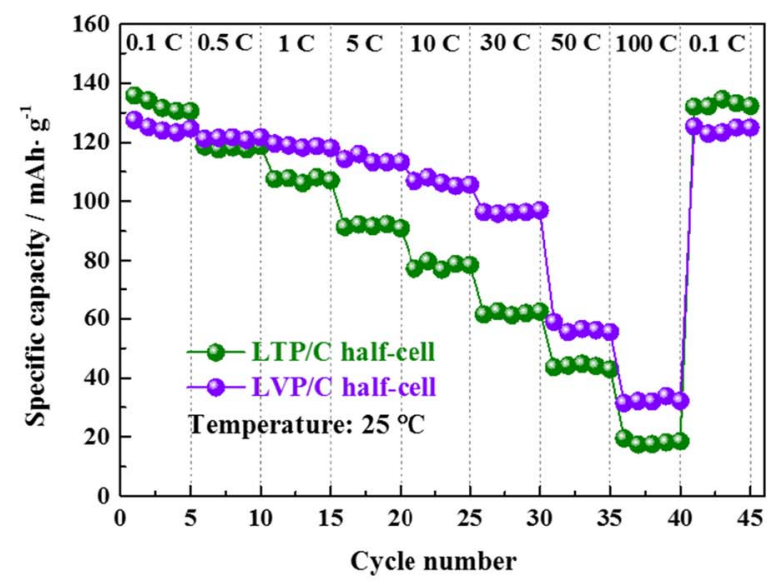

(d)

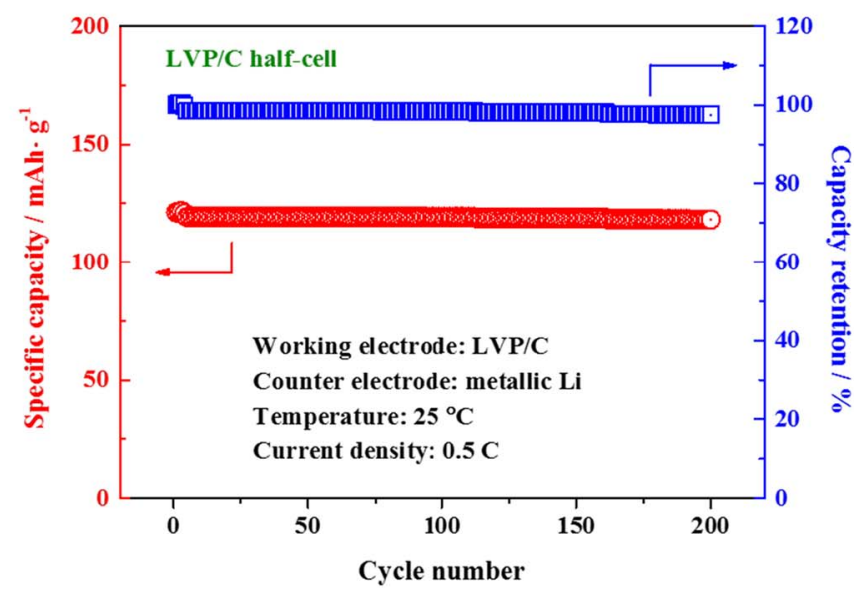

(f)

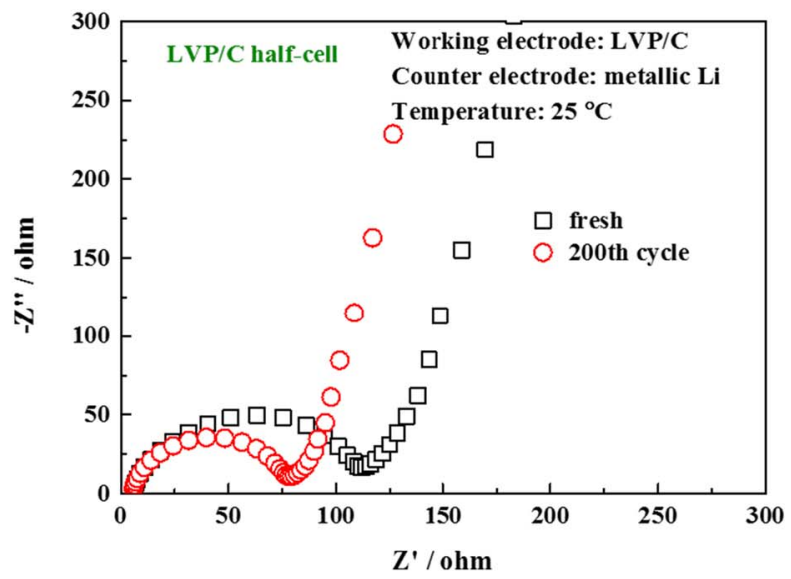

Figure 5. Electrochemical performance of spindle-like $\mathrm{LiTi}_{2}\left(\mathrm{PO}_{4}\right)_{3} / \mathrm{C}$ anode material and $\mathrm{Li}_{3} \mathrm{~V}_{2}\left(\mathrm{PO}_{4}\right)_{3} / \mathrm{C}$ needle-like cathode material. Charge-discharge profiles (a), rate capability (b), cycling performance (c) and (d), and Nyquist plots (e) and (f) of the $\mathrm{LiTi}_{2}\left(\mathrm{PO}_{4}\right)_{3} / \mathrm{C} / / \mathrm{Li}_{\text {and }} \mathrm{Li}_{3} \mathrm{~V}_{2}\left(\mathrm{PO}_{4}\right)_{3} / \mathrm{C} / / \mathrm{Li}$ half-cells.

related to the $1^{\text {st }}, 5^{\text {th }}, 50^{\text {th }}$ and $100^{\text {th }}$ cycle, which are in high agreement with the CV curve in Fig. 6a, are shown in Fig. 6d. Owing to the SEI formation and structural rearrangement of electrodes, the coulombic efficiency of first cycle was as low as $\sim 66 \%$ whereas it was close to $100 \%$ and stable for the subsequent cycles.

To evaluate the cycling stability at high current density of the LTP/C//LVP/C full cell, long-term charge-discharge in the potential range of $0.5 \sim 2.2 \mathrm{~V}$ at $5 \mathrm{C}$ was performed as shown in Fig. 7 .
The discharge capacity of the full cell decreases from initial value of $64.00 \mathrm{mAh} \cdot \mathrm{g}^{-1}$ to $22.17 \mathrm{mAh} \cdot \mathrm{g}^{-1}$ after 1000 cycles. The capacity retention was about $35 \%$. The stable delivered discharge capacity was $\sim 52 \mathrm{mAh} \cdot \mathrm{g}^{-1}$ which appeared at the cycle numbers between 300 and 500. To investigate the limitation of cycling stability, the full cell was disassembled in glove box after charge-discharge measurement. As can be seen in the images in Fig. 7, no damage formed on the LTP/C electrode after long-term cycling was observable, while the 
(a)

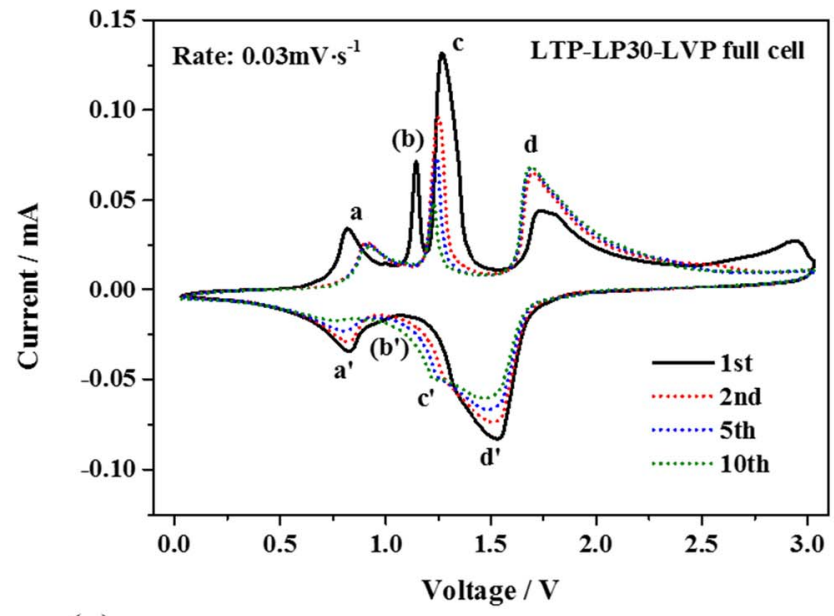

(c)

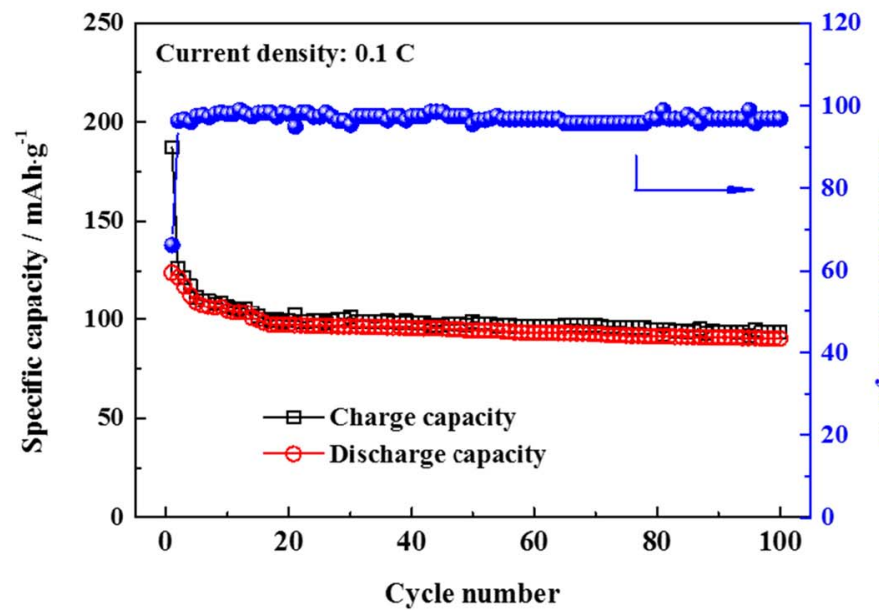

(b)

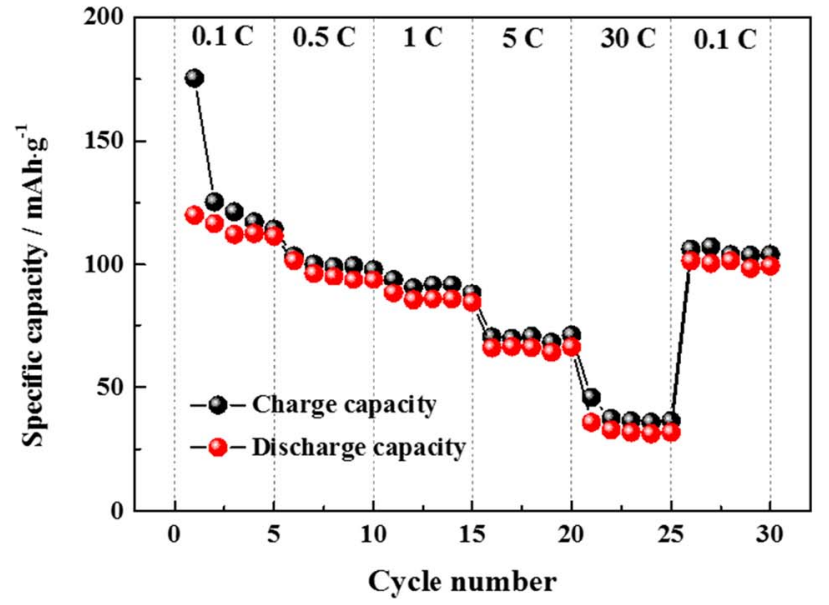

(d)

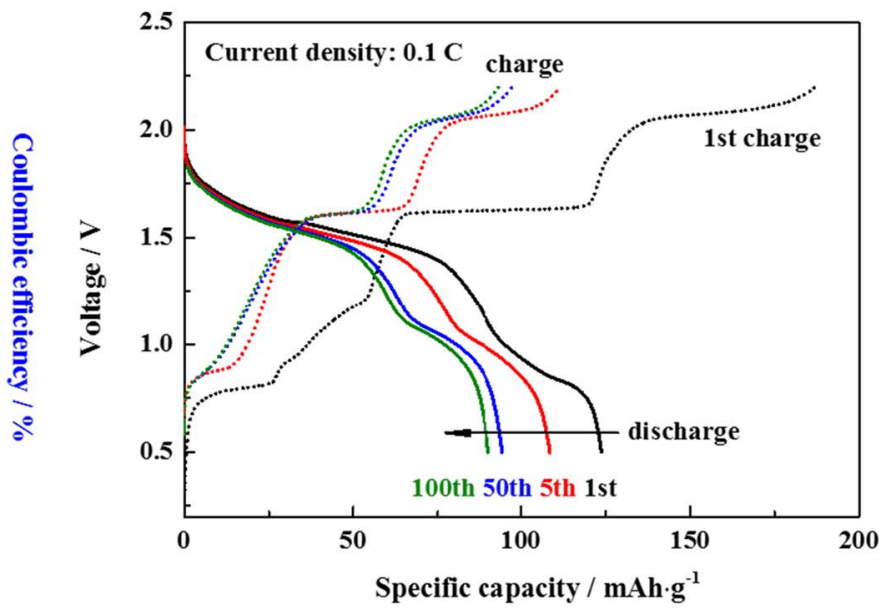

Figure 6. Electrochemical performance of $\mathrm{LiTi}_{2}\left(\mathrm{PO}_{4}\right)_{3} / \mathrm{C} / / \mathrm{Li}_{3} \mathrm{~V}_{2}\left(\mathrm{PO}_{4}\right)_{3} / \mathrm{C}$ full cell. (a) Cyclic voltammetry profile in the voltage range of 0 to $3.0 \mathrm{~V}$, (b) rate capability at $0.1 \mathrm{C}, 0.5 \mathrm{C}, 1 \mathrm{C}, 5 \mathrm{C}$ and $30 \mathrm{C},(\mathrm{c})$ cycling performance and $(\mathrm{d})$ corresponding charge-discharge profiles at $1^{\mathrm{st}}, 5^{\text {th }}, 50^{\text {th }}$ and $100^{\text {th }}$ cycle of the $\mathrm{LiTi}_{2}\left(\mathrm{PO}_{4}\right)_{3} / \mathrm{C} / / \mathrm{Li}_{3} \mathrm{~V}_{2}\left(\mathrm{PO}_{4}\right)_{3} / \mathrm{C}$ full cell.

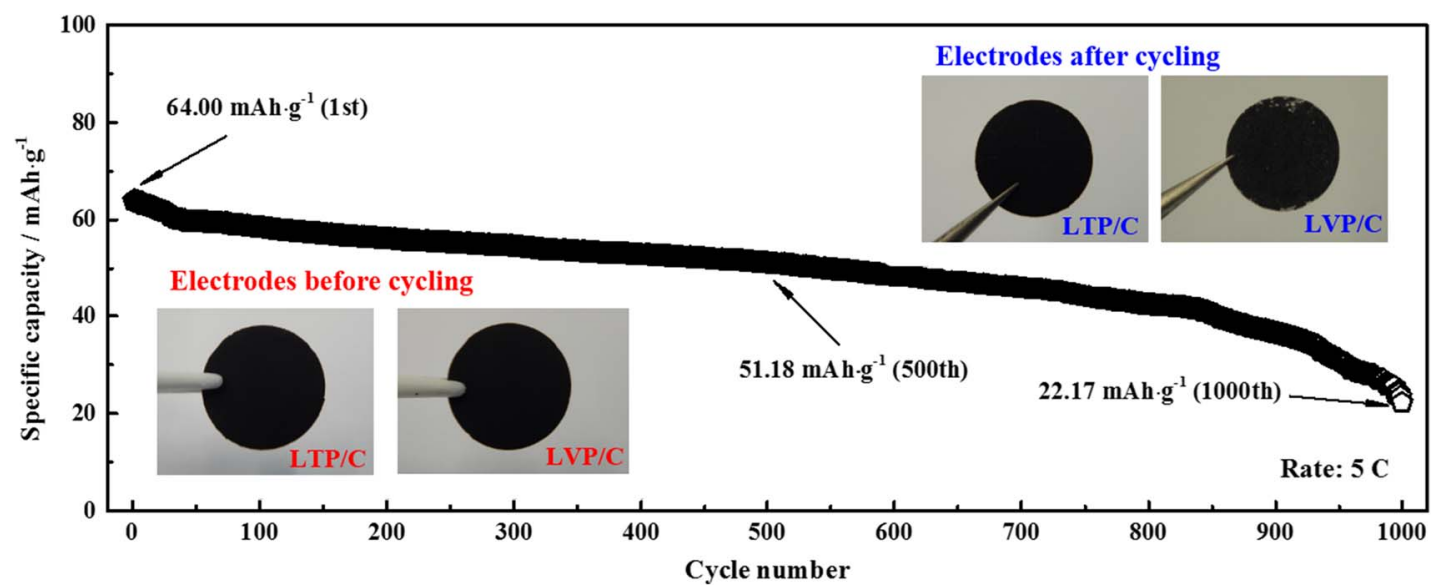

Figure 7. Cycle stability of $\mathrm{LiTi}_{2}\left(\mathrm{PO}_{4}\right)_{3} / \mathrm{C} / / \mathrm{Li}_{3} \mathrm{~V}_{2}\left(\mathrm{PO}_{4}\right)_{3} / \mathrm{C}$ full cell at $5 \mathrm{C}$ in the voltage range of $0.5 \sim 2.2 \mathrm{~V}$. The images of $\mathrm{LiTi}_{2}\left(\mathrm{PO}_{4}\right)_{3} / \mathrm{C}$ anode and $\mathrm{Li}_{3} \mathrm{~V}_{2}\left(\mathrm{PO}_{4}\right)_{3} / \mathrm{C}$ cathode before and after cycling. 
(a)

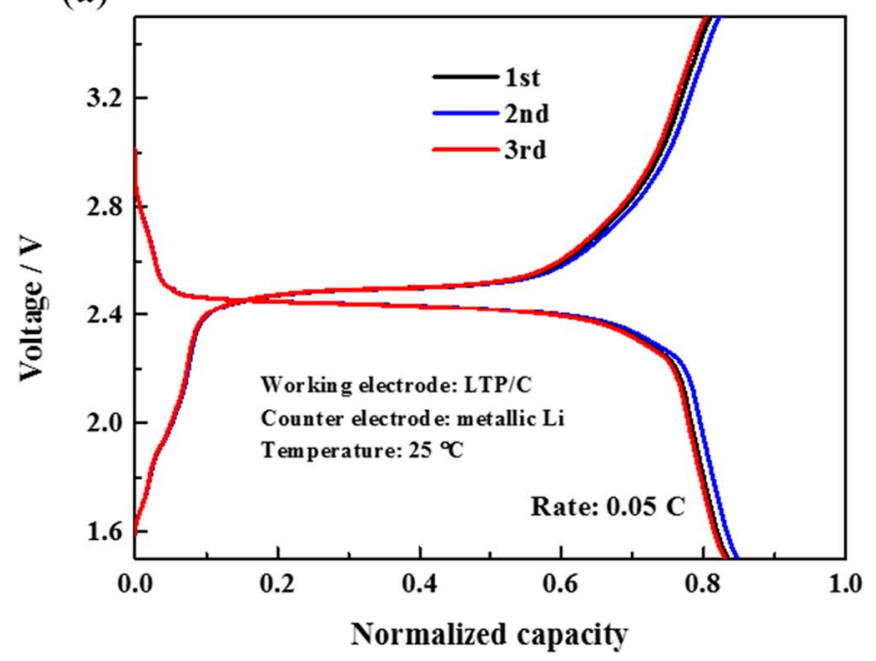

(c)

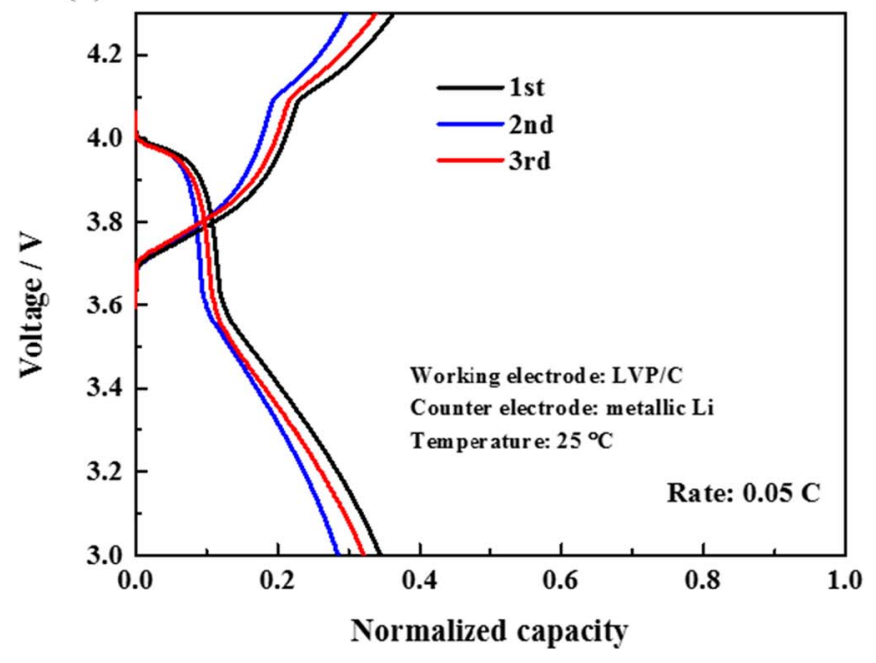

(b)

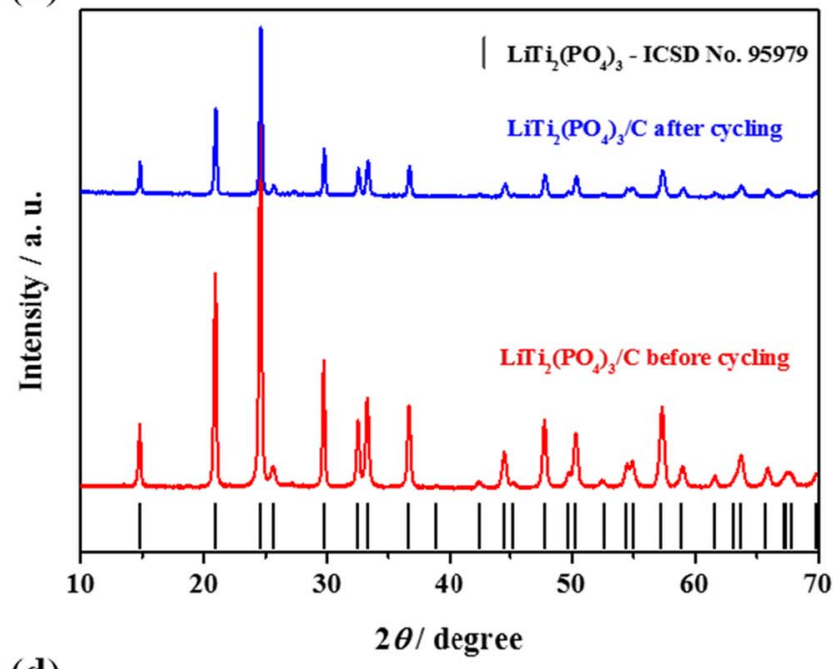

(d)

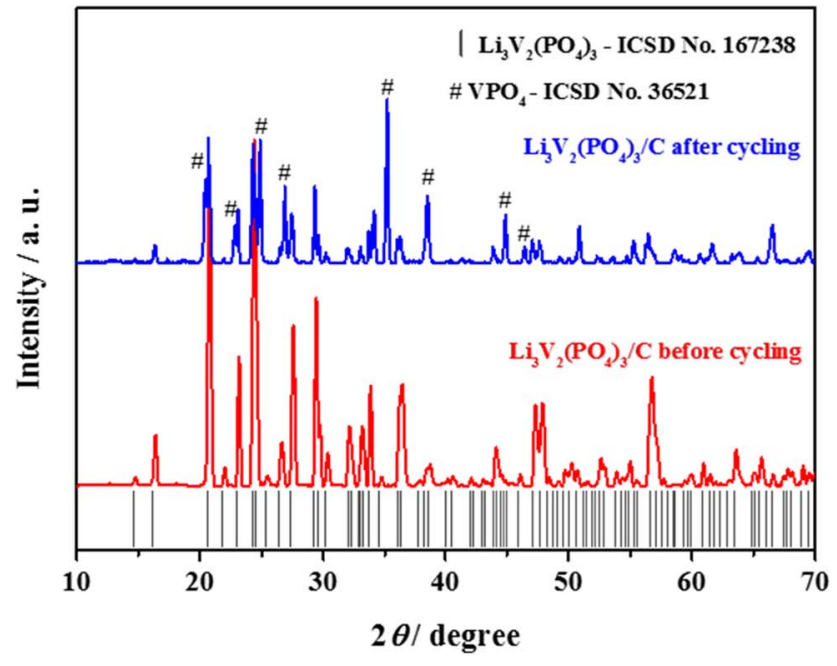

Figure 8. Charge-discharge profiles of reused $\mathrm{LiTi}_{2}\left(\mathrm{PO}_{4}\right)_{3} / \mathrm{C}$ anode (a) and reused $\mathrm{Li}_{3} \mathrm{~V}_{2}\left(\mathrm{PO}_{4}\right)_{3} / \mathrm{C}$ cathode (c) in half-cells at $0.05 \mathrm{C}$. Powder XRD patterns of $\mathrm{LiTi}_{2}\left(\mathrm{PO}_{4}\right)_{3} / \mathrm{C}(\mathrm{b})$ and $\mathrm{Li}_{3} \mathrm{~V}_{2}\left(\mathrm{PO}_{4}\right)_{3} / \mathrm{C}(\mathrm{d})$ before and after cycling.

LVP/C cathode shows degraded areas especially on the edges of the electrode. This can be the reason of the capacity fading along the cycles.

The LTP/C and LVP/C electrodes, obtained from full cell after long-term cycling at $5 \mathrm{C}$, were reused and assembled to the half-cell format in glove box with the metallic lithium as counter electrodes, respectively. The half-cells were cycled at a low current density of $0.05 \mathrm{C}$ in order to estimate the electrochemical behavior of reused electrodes. After that, the half-cells were disassembled in glove box and the active materials of LTP/C and LVP/C were carefully scraped off and washed by a mixture solvent of EC/DMC for several times, respectively. Structural analysis by XRD was carried out from the obtained powders for evaluating the structural stability of the active materials. As can be seen in Fig. 8a, even after 1000 cycles in the full cell, the reused LTP/C electrode can still deliver more than $80 \%$ of its theoretical capacity in the half-cell format. The XRD diffraction pattern (Fig. 8b) of reused LTP/C shows still the $\mathrm{LiTi}_{2}\left(\mathrm{PO}_{4}\right)_{3}$ main phase and no detectable secondary phase can be observed before and after cycling, indicating the highly structural stability and superior reversibility of LTP/C during cycling. Nevertheless, the electrochemical behavior and crystal structure of LVP/C reveal huge differences before and after cycling. The charge-discharge capacity of reused LVP/C electrode, as shown in Fig. 8c, was only around $30 \%$ of its theoretical capacity. Besides, the geometry of charge-discharge curves for the reused LVP/C electrode shows visible changes compared with that of original LVP/C half-cell which three charge-discharge plateaus can be clearly seen as shown in Fig. 5a. The corresponding XRD results of LVP/C before and after cycling are displayed in Fig. 8d. After longterm electrochemical measurement, the single phase LVP/C turned to a mixture of $\mathrm{VPO}_{4}$ and $\mathrm{Li}_{3} \mathrm{~V}_{2}\left(\mathrm{PO}_{4}\right)_{3}$ that are likely due to the crystal structural degradation caused by $\mathrm{Li}^{+}$loss during cycling. In consideration of the electrochemical performance of $\mathrm{VPO}_{4}$ as an anode in the literatures, ${ }^{50,51}$ the structural changes of LVP/C directly reflect on the electrochemical behavior of LVP/C, especially during the long-term cycling at $5 \mathrm{C}$ of the full cell.

\section{Conclusions}

In summary, an all phosphate battery of $\mathrm{LiTi}_{2}\left(\mathrm{PO}_{4}\right)_{3} / \mathrm{C} / /$ $\mathrm{Li}_{3} \mathrm{~V}_{2}\left(\mathrm{PO}_{4}\right)_{3} / \mathrm{C}$ cell with enhanced performances has been successfully prepared based on special designed spindle-like LTP/C anode and needle-like LVP/C cathode. Without conventional pre-lithiation process with metallic lithium as counter electrode, an anode-limited full cell is assembled by controlling the capacity ratio of anode and cathode while the lithium-ions from the excess cathode can make up the lithium loss for SEI formation. This type of battery displays very promising electrochemical properties in terms of rate capability and cycling life mainly attributed to the combination of high performance 
electrode materials. The LTP/C anode and LVP/C cathode were first characterized in half-cell from where their high rate capability was estimated. Even at $100 \mathrm{C}$, about $14 \%$ and $24 \%$ of their theoretical capacities were delivered respectively from LTP/C anode and LVP/C cathode. Indeed, the all phosphate full cell exhibits a discharge capacity of $35.9 \mathrm{mAh} \cdot \mathrm{g}^{-1}$ at an extremely high rate of $30 \mathrm{C}$ and capacity retention of $96.8 \%$ at $0.1 \mathrm{C}$ over 100 cycles. Moreover, the full cell shows excellent high rate cycling performance at $5 \mathrm{C}$, with a reversible capacity of $\sim 22 \mathrm{mAh} \cdot \mathrm{g}^{-1}$ after 1000 times charge-discharge. The reasons for the capacity fading over long-term cycling were estimated to be the structural degradation and phase change of LVP/C cathode. It is demonstrated that the electrode pair based on the spindle-like $\mathrm{LTP} / \mathrm{C}$ anode and needle-like LVP/C cathode is promising to meet the demand of energy storage system with low-voltage and high rate capability, for example in an all-solid-state lithium-ion battery.

\section{Acknowledgments}

This work was financially supported by the project "Ionenleiter für hocheffektive Stromspeicher" of the Ministerium für Innovation, Wissenschaft und Forschung from the Federal State of North RhineWestphalia (Germany). The SEM Quanta FEG 650 (FEI) was funded by the Bundesministerium für Forschung und Bildung (BMBF) under the Project "SABLE", Förderkennzeichen: 03EK3543. The author of S. Yu gratefully acknowledges a fellowship support by the China Scholarship Council (CSC) (No. 201306820007).

\section{References}

1. A. S. Arico, P. Bruce, B. Scrosati, J.-M. Tarascon, and W. Van Schalkwijk, Nat. Mater, 4, 366 (2005)

2. B. Dunn, H. Kamath, and J.-M. Tarascon, Science, 334, 928 (2011)

3. B. Diouf and R. Pode, Renew. Energy., 76, 375 (2015).

4. A. Farmann, W. Waag, A. Marongiu, and D. U. Sauer, J. Power Sources, 281, 114 (2015).

5. W. Wen, J.-M. Wu, Y.-Z. Jiang, J.-Q. Bai, and L.-L. Lai, J. Mater. Chem. A, 4, 10593 (2016).

6. H. Nakano, K. Dokko, J. Sugaya, T. Yasukawa, T. Matsue, and K. Kanamura, Elec trochem. Soc., 9, 2013 (2007).

7. F.-C. Liu, Z. Shadike, F. Ding, L. Sang, and Z.-W. Fu, J. Power Sources, 274, 280 (2015)

8. Y. Li, W. Zhou, S. Xin, S. Li, J. Zhu, X. Lü, Z. Cui, Q. Jia, J. Zhou, Y. Zhao, and J. B. Goodenough, Angewandte Chemie., 55, 9965 (2016).

9. L. Lu, X. Han, J. Li, J. Hua, and M. Ouyang, J. Power Sources, 226, 272 (2013).

10. J. Hassoun, K.-S. Lee, Y.-K. Sun, and B. Scrosati, J. Am. Chem. Soc., 133, 3139 (2011)

11. G.-L. Xu, Y.-F. Xu, J.-C. Fang, F. Fu, H. Sun, L. Huang, S. Yang, and S.-G. Sun, ACS Appl. Mater. Inter, 5, 6316 (2013).

12. W. Zhang, G. Ma, H. Gu, Z. Yang, and H. Cheng, J. Power Sources, 273, 561 (2015).

13. N. Membño, K. Park, J. B. Goodenough, and K. J. Stevenson, Chem. Mater, 27, 3332 (2015)
14. S. Kim, Z. Zhang, S. Wang, L. Yang, E. J. Cairns, J. E. Penner-Hahn, and A. Deb, J. Phys. Chem. C, 120, 7005 (2016).

15. T. Muraliganth, K. Strouko, and A. Manthiram, Chem. Mater, 22, 5754 (2010).

16. M. K. Devaraju, T. Tomai, A. Unemoto, and I. Honma, RSC Adv., 3, 608 (2013).

17. N. R. Khasanova, O. A. Drozhzhin, D. A. Storozhilova, C. Delmas, and E. V. Antipov, Chem. Mater, 24, 4271 (2012).

18. D. Wang, J. Xiao, W. Xu, Z. Nie, C. Wang, G. Graff, and J. -G. Zhang, J. Power Sources, 196, 2241 (2011)

19. S. Yu, H. Tempel, R. Schierholz, Ö. Aslanbas, X. Gao, J. Mertens, L. G. de Haart, H. Kungl, and R.-A. Eichel, ChemElectroChem, 3, 1157 (2016).

20. S. Yu, A. Mertens, X. Gao, D. C. Gunduz, R. Schierholz, S. Benning, F. Hausen, J. Mertens, H. Kungl, H. Tempel, and R.-A. Eichel, Func. Mater. Lett., 9, 650066 (2016).

21. S. Lee and S. S. Park, J. Phys. Chem. C, 116, 25190 (2012).

22. X. Rui, Q. Yan, M. Skyllas-Kazacos, and T. M. Lim, J. Power Sources, 258, 19 (2014).

23. H. Huang, S.-C. Yin, T. Kerr, N. Taylor, and L. F. Nazar, Adv. Mater, 14, 1525 (2002)

24. B. Pei, Z. Jiang, W. Zhang, and Z. Yang, J. Power Sources, 239, 475 (2013).

25. C.-C. Yang, S.-H. Kung, S. Lin, and W.-C. Chien, J. Power Sources, 251, 296 (2014)

26. Q. Wei, Q. An, D. Chen, L. Mai, S. Chen, Y. Zhao, K. M. Hercule, L. Xu, A. Minhas-Khan, and Q. Zhang, Nano Lett., 14, 1042 (2014).

27. L.-L. Zhang, G. Liang, G. Peng, F. Zou, Y.-H. Huang, M. C. Croft, and A. Ignatov, J. Phys. Chem. C, 116, 12401 (2012).

28. V. Aravindan, W. Chuiling, and S. Madhavi, RSC Adv., 2, 7534 (2012).

29. B. Lang, B. Ziebarth, and C. Elsässer, Chem. Mater, 27, 5040 (2015).

30. A. Svitanko, S. Novikova, I. Stenina, V. Skopets, and A. Yaroslavtsev, Inorg. Mater., 50, 273 (2014).

31. Z. Li, K. C. Smith, Y. Dong, N. Baram, F. Y. Fan, J. Xie, P. Limthongkul, W. C. Carter, and Y.-M. Chiang, Phys. Chem. Chem. Phys., 15, 15833 (2013).

32. J.-Y. Luo and Y.-Y. Xia, Adv. Funct. Mater., 17, 3877 (2007).

33. P. Jakes, J. Granwehr, H. Kungl, and R.-A. Eichel, Z. Phys. Chem., 229, 1439 (2015).

34. K. Dokko, S. Koizumi, and K. Kanamura, Chem. Lett., 35, 338 (2006).

35. J. Chen and J. Graetz, ACS Appl. Mater. Inter, 3, 1380 (2011).

36. K. Dokko, S. Koizumi, K. Sharaishi, and K. Kanamura, J. Power Sources, 165, 656 (2007).

37. C. Sun, S. Rajasekhara, Y. Dong, and J. B. Goodenough, ACS Appl. Mater. Inter, 3 3772 (2011).

38. L. Wang, J. Bai, P. Gao, X. Wang, J. P. Looney, and F. Wang, Chem. Mater, 27, 5712 (2015).

39. Y. Yue, W. Pang, and J. Mater. Sci. Lett., 9, 1392 (1990).

40. H.-K. Roh, H.-K. Kim, K.C. Roh, and K.-B. Kim, RSC Adv., 4, 31672 (2014)

41. L. Chen, B. Yan, J. Xu, C. Wang, Y. Chao, X. Jiang, and G. Yang, ACS Appl. Mater. Inter, 7, 13934 (2015)

42. R. Zhang, Y. Zhang, K. Zhu, F. Du, Q. Fu, X. Yang, Y. Wang, X. Bie, G. Chen, and Y. Wei, ACS Appl. Mater. Inter., 6, 12523 (2014)

43. H. El-Shinawi and J. Janek, RSC Adv., 5, 14887 (2015).

44. S. N. Agbo, T. Merdzhanova, S. Yu, H. Tempel, H. Kungl, R.-A. Eichel, U. Rau, and O. Astakhov, J. Power Sources, 327, 340 (2016).

45. S. N. Agbo, T. Merdzhanova, S. Yu, H. Tempel, H. Kungl, R.-A. Eichel, U. Rau, and O. Astakhov, Phys. Status Solidi A, 213, 1926 (2016).

46. Z. Liu, X. Qin, H. Xu, and G. Chen J. Power Sources, 293, 562 (2015).

47. J. Sun, Y. Sun, L. Gai, H. Jiang, and Y. Tian, Electrochim. Acta, 200, 66 (2016).

48. M. Zhou, L. Liu, L. Yi, Z. Yang, S. Mao, Y. Zhou, T. Hu, Y. Yang, B. Shen, and X. Wang, J. Power Sources, 234, 292 (2013).

49. A. Mertens, I. C. Vinke, H. Tempel, H. Kungl, L. G. J. de Haart, R.-A. Eichel, and J. Granwehr, J. Electrochem. Soc., 163, H521 (2016).

50. J.-C. Zheng, Y.-D. Han, B. Zhang, C. Shen, L. Ming, X. Ou, and J.-F. Zhang, ACS Appl. Mater. Inter, 6, 6223 (2014)

51. Y. Zhang, X. Zhang, Q. Tang, D. Wu, and Z. Zhou, J. Alloys Compd., 522, 167 (2012). 